DEPARTMENT OF THE INTERIOR UNITED STATES GEOLOGICAL SURVEY

\title{
BIBLIOGRAPHY OF PUBLISHED RADIOCARBON DATES \\ FOR ALASKA
}

\section{by}

John P. Galloway

\section{OPEN-FILE REPORT \\ $84-21$}

This report is preliminary and has not been edited or revised for conformity with

U.S.G.S. editorial standards and stratigraphic nomenclature 
CONTENT

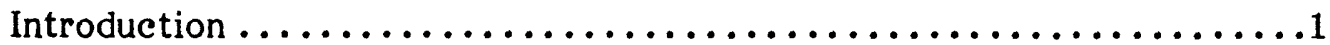

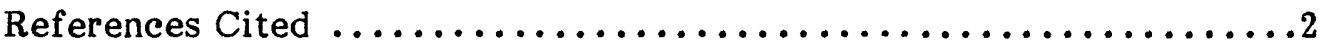

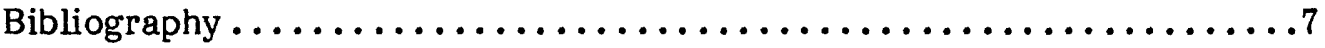

Illustration

Figure 1 - Geographic divisions used for Appendix IV and V.........37

Appendix

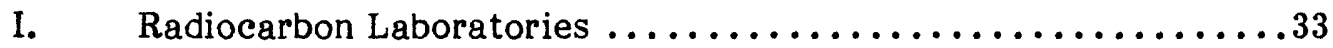

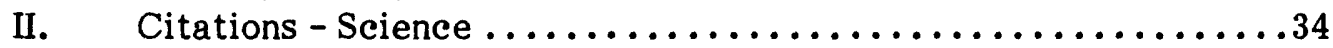

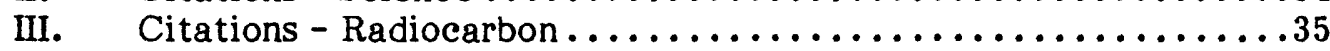

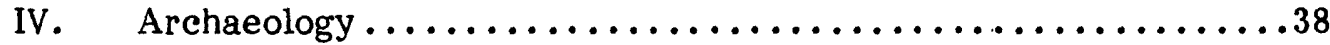

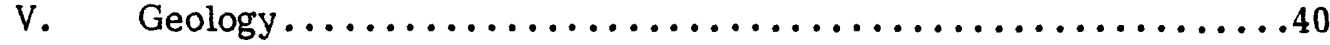




\section{INTRODUCTION}

Since publication of the first radiocarbon dates for Alaska was reported (Arnold and Libby 1951) more than 1,900 radiocarbon age determinations have been reported for geological and archaeological samples from Alaska. Thirty-one U. S. laboratories (commercial, university, State, Federal) and eleven foreign laboratories (listed in Appendix () have reported radiocarbon ages in Radiocarbon and other scientific journals. Before the first publication of Radiocarbon (originally the Radiocarbon Supplement to American Journal of Science), in 1959, radiocarbon date lists were routinely published in Science. Date lists published in Science (1951 to 1958) are listed in Appendix II. Citations, by laboratories, for Alaskan samples published in Radiocarbon are listed in Appendix III.

The purpose of this bibliography is to cite and index publications which mention radiocarbon dates for Alaska. Criteria for inclusion of a reference in this bibliography were the mention of either: 1) a date and laboratory number, or 2) a date with a standard deviation. Publications which contained a radiocarbon date(s) only were excluded. More than 375 geological and archaeological references make up this bibliography. Citations were indexed according to subject (archaeology or geology) then further subdivided according to geographic area. Figure 1 shows the geographic divisions used in this report. Appendix IV (archaeology) and V (geology) lists citations by author(s) and geographic area.

The more than 375 geological and archaeological publications listed in this bibliograpny were located by manual library techniques. A literature search of both geological and archaeological journals was undertaken. Although completeness was strived for, this bibliography has not benefitted from a thorough search of all doctoral and masters' dissertations (geologic and archaeologic) relating to Alaska. The largest source for radiocarbon dates were the various U. S. Geological Survey publications (Bulletins, Circulars, Professional Papers, and Open-File Reports) which contained more than forty references. Two excellent sources for radiocarbon dates, geologic samples, were the journals Arctic and Quaternary Research (17 and 13 citations respectively). An excellent source for radiocarbon dates relating to anthropological material were Arctic Anthropology and Anthropological Papers of the University of Alaska (20 and 19 citations respectively).

Although Appendix IV and $V$ list the citations by author and region the following is a listing of key references by subject and regions:

ARCHAEOLOGY - Northern: Anderson, 1970; Gal, 1982; Hamilton, 1979; Stanford, 1976; West-Central: West, 1978; East-Central: Cook, 1969; Southwestern: Aigner, 1978; Black, 1976; Clark, D., 1979; Workman, 1977; Southern: Bowers, 1980; Schweger, 1981; Thorson and Hamilton, 1977; Southeastern: Ackerman, et. al., 1979.

GEOLOGY - State: Péwé, 1975a; 1975b; Northern: Brown, 1965; Calkin and Ellis, 1980; Carson, 1968; Hamilton, 1982; Schweger, 1982; West-Central: Guthrie and Matthews, 1971 ; East-Central: Ager, 1982; Fernald, 1965a; 1965b; Péwé, 1965a; 1965b; 1965c; Thorson and Dixon, 1983; Southwestern: Black, 1976; 1974; Heusser, 1973; Southern: Denton, 1974; Denton and Karlen, 1977; Reger and Updike, 1983; Thorson, et. al., 1981; Southeastern: Goldthwait, 1966; McKenzie and Goldthwait, 1971. Several key reterences pertaining to vertebrate remains are: Guthrie, 1976; 1968; Harington, 1980; 1978; and Porter, 1979. For the Beaufort and Chuckchi Coast see: Hopkins and Robinson, 1981; 1979a; 1979b; Hopkins, et. al., 1981. 
The primary emphasis of this report is the citation of radiocarbon dates for Alaska. Yet changes, both archaeologic and geologic, occurred in adjacent countries, Canada and U.S.S.R., which directly affected events in Alaska. As an introduction to the radiocarbon literature for Canada and U.S.S.R. I have included several key references. For the U.S.S.R., particularly Siberia, papers by Chard and Powers, 1968; Kind, 1967; Klein, 1967, 1971; Svitoch, 1978; Svitoch, et. al., 1978, are quite useful. Useful references for Canada are: British Columbia: Borden, 1979; Clague, et. al., 1982a; Clauge, et. al., 1982b; Wilson and Young, 1976; Northwest Territories: Andrews, 1975; Andrews and Miller, 1972; McGhee and Tuck, 1976; Yukon Territories: Denton, 1974; Denton and Karlen, 1977; Harington, 1980, 1978; Hopkins, et. al., 1981; Hughes, et. al., 1981; Irving and Harington, 1973; Jopling, et. al., 1981; Lowdon and Blake, 1979; Morlan, 1980; Thorson and Dixon, 1983; Wilson and Young, 1976.

\section{REFERENCES CITED}

Ackerman, R. E., Hamilton, T. D., and Stuckenrath, R., 1979, Early Culture Complexes on the Northern Northwest Coast: Canadian Journal of Archaeology, no. 3, p. 195209.

Ager, T. A., 1982, Vegetational history of western Alaska during the Wisconsin glacial interval and the Holocene, in, Hopkins, D. M., Matthews, J. V., Jr., Schweger, C. E., and Young, S. P., eds., Paleoecology of Beringia, Academic Press, New York, p. 7594.

Aigner, J. S., 1978, Dating the early Holocene maritime village of Anangula: Anthropological Papers of the University of Alaska, v. 19, no. 1, p. 51-62.

Anderson, D. D., 1970, Miicroblade traditions in Northwestern Alaska: Arctic Anthropology, v. 7, no. 2, p. 2-16.

Andrews, J. T., 1975, Radiocarbon date list II from Cumberland Peninsula, Baffin Island, N.W.T., Canada: Arctic and Alpine Research, v. 7, no. 1, p. 77-91.

Andrews, J. T., and Miller, G. H., 1972, The Quaternary history of Northern Cumberland Peninsula, East Baffin Island, N.W.T., Part X: Radiocarbon date list: Arctic and Alpine Research, v. 4, no. 3, p. 261-277.

Arnold, J . R., and Libby, W. F., 1951, Radiocarbon dates: Science, v. 113, p. 111-120.

Black, R. F., 1976, Geology of Umnak Island, eastern Aleutian Islands as related to the Aleuts: Arctic and Alpine Research, v. 8, no. 1, p. 7-35.

Black, R. F., 1974, Late-Quaternary sea-level changes, Umnak Island, Aleutians; their effects on ancient Aleuts and their cause: Quaternary Research, v. 4, no. 3, p. 264281.

Borden, C. E., 1979, Peopling and early cultures of the Pacific Northwest: Science, v. 203, no. 4384, p. 963-971.

Bowers, P. ivl., 1980, The Carlo Creek site: geology and archaeology of an early Holocene site in the Central Alaska Range: Anthropology and Historic Preservation Cooperative Park Studies Unit, University of Alaska, Occasional Paper No. 27, 209 p. 
Brown, J., 1965, Radiocarbon dating, Barrow, Alaska: Arctic, v. 18 no. 1, p. 37-48.

Calkin, P. E., and Ellis, J. M., 1980, A lichenometric dating curve and its application to Holocene glacier studies in the Central Brooks Range: Arctic and Alpine Research, v. 12 , no. 3, p. 245-264.

Carson, C. t., 1968, Radiocarbon dating of lacustrine strands in arctic Alaska: Arctic, v. 21 , no. 1 , p. 12-26.

Chard, C. S., and Powers, R., 1968, Soviet archaeological radiocarbon dates: III: Arctic Anthropology, v. 5, no. 1, p. 224-233.

Clague, J, Harper, J. R., Hebda, R. J., and Howes, D. E., 1982a, Late Quaternary sea level and crustal movement, coastal British Columbia: Canadian Journal of Earth Science, v. 19, no. 3, p. 597-618.

Clague, J. J., Mathewes, R. W., and Warner, B. G., 1982b, Late Quaternary geology of eastern Graham Island, Queen Charlotte Island, British Columbia: Canadian Journal of Earth Science, v. 19, no. 9, p. 1786-1795.

Clark, D. W., 1979, Ocean Bay: an early North Pacific Maritime Culture: National Museum of Man Mercury Series, Archaeological Survey of Canada Paper No. 86, 404 p.

Cook, J. P., 1969, The early Prehistory of Healy Lake, Alaska: Ph.d. dissertation, University of $W$ isconsin.

Denton, G. H., 1974, Quaternary glaciations of the White River Valley, Alaska, with a regional synthesis for the northern St. Elias Mountains, Alaska and Yukon Territory: Geological Society of America Bulletin, v. 85, no. 6, p. 871-892.

Denton, G. H., and Karlen, W., 1977, Holocene glacial and tree-line variations in the White Kiver Valley and Skolai Pass, Alaska and Yukon Territory: Quaternary Research, v. 7, no. 1. p. 63-111.

Fernald, A. T., 1965a, Late Quaternary chronology, Upper Tanana River Valley, Eastern Alaska: Geological Society of America Special Paper no. 82, p. 60-61.

Fernald, A. T., 1965b, Recent history of the upper Tanana River Lowland, Alaska, U. S. Geologcal Survey Professional Paper 525C, p. C124-C127.

Gal, R., 1982, Appendix I: an annotated and indexed roster of archaeological radiocarbon dates from Alaska, north of $68^{\circ}$ latitude: Anthropological Papers of the University of Alaska, v. 20, no. 1-2, p. 159-180.

Goldthwait, R. P., 1966, Glacial history, in, Mirsky, A., ed., Soil development and ecological sucession in a deglaciated area of Muir Inlet, southeast Alaska: Ohio State University, Institute of Polar Studies Paper No. 20, p. 1-18.

Guthrie, R. U., 1976, Terrestrial vertebrates and their effect in the distribution of human habitation sites, in, Bering Land Bridge Cultural Resource Study, Final Report, University of Alaska Museum, Fairbanks, Alaska, p. 115-145. 
Guthrie, R. D., 1968, Paleoecology of a Late Pleistocene small mammal community from Interior Alaska: Arctic, v. 21, no. 4, p. 223-244.

Hamilton, T. D., 1982, A late Pleistocene glacial chronology for the southern Brooks Range; stratigraphic record and regional significance: Geological Society of America Bulletin, v. 93, no. 8, p. 700-716.

Hamilton, T. D., 1979, Radiocarbon dates and Quaternary stratigraphic sections Philip Smith Mountains quadrangle, Alaska: U. S. Geological Survey Open-File Report 79866, 43 p.

Harington, C. K., 1980, Radiocarbon dates on some Quaternary mammals and artifacts frorn northern North America: Arctic, v. 33, no. 4, p. 815-832.

Harington, C. R., 1978, Quaternary vertebrate faunas of Canada and Alaska and their suggested chronological sequence: Syllogeus, no. 15, National Museums of Canada, Ottowa, Canada, 105 p.

Heusser, C. J., 1973, Postglacial vegetation in Umnak Island, Aleutian Islands, Alaska: Review of Palaeobotany and Palynology, v. 15, p. 277-285.

Hopkins, D. M., and Robinson, S. W. 1981, Radiocarbon dates from the Beaufort and Chukchi Sea Coasts 1980-1981, in, Hopkins, D. M., and Smith, P. A., U.S. National Oceanic and Atmospheric Admin. Environmental Assessment of the Alaska Continental Shelf Annual Report of Principal Investigations for the year ending March 1981, Appendix C, p. 191-193.

Hopkins, D. M., and Robinson, S. W., 1979a, Radiocarbon dates from the Beaufort and Chukchi Sea Coast, in, Johnson, K. M., and Williams, J. R., eds., The U. S. Geological Survey in Alaska - Accomplishments during 1978: U. S. Geological Survey Circular 804-B, p. 44-46.

Hopkins, D. M., and Robinson, S. W., 1979b, Radiocarbon dates from the Chukchi and Beaufort Sea Coast, in, Smith, P. and Hopkins, D., U.S. National Oceanic and Atmospheric Admin. Environmental Assessment of the Alaska Continental Shelf Annual Report of Principal Investigations for the year ending March 1979, Appendix 4, p. 156-163.

Hopkins, D. M., Robinson, S. W., and Buckley, J., 1980, Radiocarbon dates from the Beaufort and Chukchi Sea Coast (1979-1980), in, Smith, P., Hartz, R., and Hopkins, D., U.S. National Oceanic and Atmospheric Admin. Environmental Assessment of the Alaska Continetnal Shelf Annual Report of Principal Investigations for the year ending March 1980, Appendix E, p. 203-220.

Hopkins, D. M., Smith, P. A., and Matthews, J. V., Jr., 1981, Dated wood from Alaska and the Yukon; implications for forest refugia in Beringia: Quaternary Research, v. 15, no. 3, p. 217-249.

Hughes, O. L., Harington, C. R., Janssens, J. A., Matthews, J. V., Jr., Morlan, R. E., Rutter, N. W., and Schweger, C. E., 1981, Upper Pleistocene stratigraphy, paleoecology, and archaeology of the northern Yukon Interior, eastern Beringia 1 Bonnet Plume Basin: Arctic, v. 34, no. 4, p. 329-365. 
Irving, W. N., and Harington, C. R., 1973, Upper Pleistocene radiocarbon dated artefacts from the Northern Yukon: Science, v. 179, no. 4071, p. 335-340.

Jopling, A. V., Irving, W. N., and Beebe, B. F., 1981, Stratigraphic, sedimentological and faunal evidence for the occurrence of pre-Sangamonian artefacts in Northern Yukon: Arctic, v. 34, no. 1, p. 3-33.

Kind, N. V., 1967, Radiocarbon chronology in Siberia, in, Hopkins, D. M., ed., The Bering Land Bridge, Stanford University Press, CA., p. 172-192.

Klein, K. G., 1971, The Pleistocene prehistory of Siberia: Quaternary Research, v. 1, no. 2, p. 133-161.

Klein, R. G., 1967, Radiocarbon dates on occupation sites of Pleistocene age in the U.S.S.R.: Arctic Anthropology, v. 4, no. 2, p. 224-226.

Lowdon, J. A., and Blake, W., Jr., 1979, Geological Survey of Canada radiocarbon dates XIX: Geological Survey of Canada Paper 79-7, 58 p.

McGhee, R, and Tuck, J. A., 1976, Un-dating the Canadian Arctic, in, Maxwell, M. S., ed., Eastern Arctic Prehistory: Paleoeskimo Problems, Memoirs of the Society for American Archaeology, no. 31, p. 6-14.

McKenzie, G. D., 1970, Glacial geology of Adams Inslet, southeastern Alaska: Ohio State University, Institute of Polar Studies Report 25, $121 \mathrm{p}$.

McKenzie, G. D., and Goldthwait, R. P., 1971, Glacial history of the last eleven thousand years in Adams Inlet, Southeastern Alaska: Geological Society of America, Bulletin, v. 82 , no. 7, p. 1767-1782.

Miorlan, R. E., 1980, Taphonomy and archaeology in the upper Pleistocene of the northern Yukon Territory: a glimpse of the peopling of the New World: National Museum of Man Mercury Series, Archaeological Survey of Canada Paper No. 94, 398 p.

Péwé, T. L., 1975a, Quaternary geology of Alaska: U. S. Geologcal Survey Professional Paper 835, 145 p.

Péwé, T. L., 1975b, Quaternary stratigraphic nomenclature in unglaciated Central Alaska: U. S. Geologcal Survey Professional Paper 862, 32 p.

Péwé, 1. L., 1965a, Fairbanks area, in, Schultz, C. B., and Smith, H. T. U., eds., International Association for Quaternary Research, VIIth Congress, Guidebook for Field Conterence F, central and south central Alaska: Nebraska Academy of Science, Lincoln, Nebraska, p. 6-36.

Péwé, T. L., 1965b, Resurne of the Quaternary geology of the Middle Tanana River Valley, in, Schultz, C. B., and Smith, H. T. U., eds., International Association for Quaternary Research, VIIth Congress, Guidebook for Field Conference F, central and south central Alaska: Nebraska Academy of Science, Lincoln, Nebraska, p. 36-54.

Péwé, T. L., 1965c, Resume of Quaternary Geology of the Delta River Area, Alaska Range, in, Schultz, C. B., and Smith, H. T. U., eds., International Association for Quaternary Research, VIIth Congress, Guidebook for Field Conference F, central and south central Alaska: Nebraska Academy of Science, Lincoln, Nebraska, p. 55-93. 
Porter, L., 1979, Ecology of a Late Pleistocene (Wisconsin) ungulate community near Jack Wade, East-Central Alaska: Master's thesis, University of Washington, 85 p.

Reger, R. D., and Updike, R. G., 1983, Upper Cook Inlet Region and the Matanuska Valley, in, Péwé, T. L., and Reger, R. D., eds., Guidebook to Permafrost and Quaternary Geology along the Richardson and Glenn Highways between Fairbanks and Anchorage, Alaska, Fourth International Conference on Permafrost, Guidebook 1, p. 185-263.

Schweger, C. E., 1982, Late Pleistocene vegetation of eastern Beringia: pollen analysis of dated alluvium, in, Hopkins, D. M., Matthews, J. V., Jr., Schweger, C. E., and Young, S. P., eds., Paleoecology of Beringia, Academic Press, New York, p. 95-112.

Schweger, C. E., 1981, Chronology of Late Glacial events from the Tangle Lake, Alaska Range, Alaska: Arctic Anthropology, v. 18, no. 1, p. 97-101.

Stanford, D. J., 1976, The Walakpa site, Alaska; its place in the Birnirk and Thule Cultures: Smithsonian Contributions to Anthropology, no. 20., Smithsonian Institutition Press, Washington, D.C., 226 p.

Svitoch, A. A., 1978, Correlation of late Pleistocene and Holocene events in Chukotka, Alaska and northwestern Siberia on the basis of radiocarbon dates: Doklady Akademii Nauk S.S.R., v. 232, no. 5, p. 110-112.

Svitoch, A. A., Parunin, O. B., Sarazhinskaya, N. I., Timashkova, T. A., and Shlyukov, A. I., 1978, Radiocarbon age and correlation of late Pleistocene sediments of Chukotka: Doklady Akademii Nauk S.S.R., v. 233, no. 2, p. 69-72.

Thorson, R. M., and Dixon, E. J., Jr., 1983, Alluvial history of the Porcupine River, Alaska - role of glacial-lake overflow from northwest Canada: Geological Society of America Bulletin, v. 94, no. 5, p. 576-589.

Thorson, R. M., and Hamilton, T. D., 1977, Geology of the Dry Creek Site; a stratified early man site in interior Alaska: Quaternary Research, v. 7, no. 2, p. 149-176.

Thorson, R. M., Dixon, E. J., Jr., Smith, G. S., and Batten, A. R., 1981, Insterstadial proboscidean from south-central Alaska; implications for biogeography, geology, and archaeology: Quaternary Research, v. 16 no. 3, p. 404-417.

West, C. E., 1978, Archaeology of the Birches sites, Lake Minchumia, Alaska: unpublished master's thesis, University of Alaska, $179 \mathrm{p}$.

Wilson, F. H., and Young, M. S., 1976, Radiocarbon dates for Alaska, Yukon Territory and British Columbia: Institute of Marine Science, University of Alaska, IMS Report R76-6, 64 p.

Workman, W. B., 1977, New data on the radiocarbon chronology of the Kachemak Bay Sequence: Anthropological Papers of the University of Alaska, v. 18, no. 2, p. 31-36. 


\section{BIBLIOGRAPHY}

Ackerman, K. E., 1973, Post Pleistocene Cultural Adaptations on the Northern Northwest Coast, in, Kaymond, S., and Schledermann, P., eds., International Conference on the Prehistory and Paleoecology of Western Arctic and Sub-Arctic, University of Calgary Archaeological Association, Calgary, Canada, p. 1-20.

Ackerman, R. E., 1964, Prehistory in the Kuskokwin-Bristol Bay region, southwestern Alaska: Washington State University Laboratory of Anthropology, Report of Investigations No. 26.

Ackerman, K. E., 1962, Culture contact in the Bering Sea: Birnik-Punuk Period: Institute of North America Technical Paper No. 11, p. 27-34, (no lab. numbers).

Ackerman, R. E., Hamilton, T. D., and Stuckenrath, R., 1979, Early Culture Complexes on the Northern Northwest Coast: Canadian Journal of Archaeology, no. 3, p. 195209.

Ager, T. A., 1982, Vegetational history of western Alaska during the Wisconsin glacial interval and the Holocene, in, Hopkins, D. M., Matthews, J. V., Jr., Schweger, C. E., and Young, S. P., eds., Paleoecology of Beringia, Academic Press, New York, p. 7594.

Ager, T., 1976, Holocene vegetational history of the Lake Minchumina area, Mt. McKinley quadrangle, Alaska: American Quaternary Association Fourth Biennial Meeting, Tempe, Arizona, (abs.) p. 96.

Ager, T. A., 1975, Late Quaternary environmental history of the Tanana Valley, Alaska: Ohio State University, Institute of Polar Studies Report No. 54, 117 p.

Ager, 1. A., 1972, Surficial geology and Quaternary history of the Healy Lake area, Alaska: University of Alaska unpublished M.S. thesis, 127 p.

Ager, T. A., and Sims, J. D., 1981 a, Holocene pollen and sediment record from the Tangle Lakes area, central Alaska: Palynology, v. 5, p. 85-98.

Ager, T. A., and Sims, J. D., 1981b, Late Quaternary pollen record from Hidden Lake, Kenai Peninsula, Alsaka: American Association of Stratigraphic Palynologists, 14th Annual Meeting, New Orleans, La., Program and Abstracts, p. 8-9.

Aigner, J. S., 1978a, The Lithic Remains from Anangula: Institut fur Urgeschichte der Universitat Tubingen, Tubingen, West Germany.

Aigner, J. S., 1978b, Activity zonation in a 4000 year old Aleut house, Chaluka Village, Umnak Island, Alaska: Anthropological Papers of the University of Alaska, v. 19, no. 1, p. 17-25.

Aigner, J. S., 1978c, Dating the early Holocene maritime village of Anangula: Anthropological Papers of the University of Alaska, v. 19, no. 1, p. 51-62.

Aigner, J. S., Fullem, B., Veltre, D., and Veltre, M., 1976, Preliminary reports on remains from Sandy Beach Bay; a 4300-5600 B.P. Aleut village: Arctic Anthropology, v. 13, no. 2, p. 83-90. 
Alexander, H. L., 1974, The association of Aurignacoid elements with fluted point complexes in North America, in, Raymond, S., and Schledermann, P., eds., International Conference on Prehistory and Paleoecology of Western North America, University of Calgary Archaeological Association, Calgary, Canada, p. 21-31.

Alexander, H. L., Jr., 1969, Prehistory of the Central Brooks Range and archaeological analysis: unpublished Ph.D. Dissertation, University of Oregon.

Anderson, D. D., 1978, Western arctic and sub-arctic, in, Taylor, R. E., and Meigham, C. W., eds., Chronologies in New World Archaeology, Acadernic Press, New York.

Anderson, D. D., 1970a, Microblade traditions in Northwestern Alaska: Arctic Anthropology, v. 7, no. 2, p. 2-16.

Anderson, D. D., 1970b, An early archaeological assemblage from Onion Portage Northwest Alaska: Acta Arctica, v. 16, p. 1-80.

Archaeological Research Inc., 1970, Archaeological Report -Amchitka Island, Alaska 1969-1970: U.S. Atomic Energy Commission, Division of Technical Information TID$25481,396 \mathrm{p}$.

Arnold, J . R., and Libby, W. F., 1951, Radiocarbon dates: Science, v. 113, p. 111-120.

Barendsen, G. W., Deevey, E. S., and Gralensk, L. J., 1957, Yale natural radiocarbon measurements III: Science, v. 126, no. 3279, p. 908-919.

Barr, L., Ellis, R. J., and Ellis, J. H., 1973, Fossil tree stumps found insitu on submerged ridge at Amchitka Island, Alaska: Fishery Bulletin, v. 71, no. 4, p. 1099-1103. (no lab. number)

Bender, M. M., Baerreis, D. A., Bryson, R. A., and Steventon, R. L., 1982, University of Wisconsin radiocarbon dates XIX: Radiocarbon, v. 24, no. 1, p. 83-100.

Bartsch-Winkler, S., Ovenshine, A. T., and Kachadoorian, R., 1983, Holocene history of the estuarine area surrounding Portage, Alaska as recorded in a $93 \mathrm{~m}$ core: Canadian Journal of Earth Science, v. 20, no. 5, p. 802-820.

Black, R. F., 1976a, Geology of Umnak Island, eastern Aleutian Islands as related to the Aleuts: Arctic and Alpine Research, v. 8., no. 1, p. 7-35.

Black, R. F., 1976b, Late-Quaternary glacial events, Aleutian Islands Islands, Alaska, in, Easterbrook D. J., and Sibrava, V., eds., Project 73/1/24 Quaternary Glaciations in the Northern Hemisphere, IUGS UNESCO International Geological Correlation Program, $374 \mathrm{p}$.

Black, R. F., 1975, Late-Quaternary geomorphic processes; effects on the ancient Aleuts of Umnak Island in the Aleutians: Arctic, v. 28, no. 3, p. 159-169. (no lab. numbers)

Black, R. F., 1974, Late-Quaternary sea-level changes, Umnak Island, Aleutians; their effects on ancient Aleuts and their cause: Quaternary Research, v. 4, no. 3, p. 264281.

Black, K. F. and Laughlin, W. S., 1964, Anangula: a geologic interpretation of the oldest archaeological site in the Aleutians: Science v. 143, no. 3612, p. 1321-1322. 
Blackwell, M. F., 1965, Surficial geology and geomorphology of the Harding Lake area, Big Delta quadrangle, Alaska: University of Alaska unpublished M.S. Thesis, 91 p.

Bonnichsen, R., 1979, Pleistocene bone technology in the Beringian Refugium: National Museum of Man Mercury Series, Archaeological Survey of Canada Paper No. 89, 297 p.

Borden, C. E., 1979, Peopling and early cultures of the Pacific Northwest: Science, v. 203, no. 4384, p. 963-971.

Borden, C. E., 1962, West Coast crossities with Alaska: Arctic Institute of North America Technical Paper No. 11, p. 9-19.

Bowers, P. M., 1980, The Carlo Creek site: geology and archaeology of an early Holocene site in the Central Alaska Range: Anthropology and Historic Preservation Cooperative Park Studies Unit, University of Alaska, Occasional Paper No. 27, 209 p.

Bowers, P. M., 1978a, Geology and archaeology of the Carlo Creek site, an early Holocene campsite in the Central Alaska Range: American Quaternary Association ritth Biennial Meeting, Edmonton, Alberta, Canada (abs.) p. 188.

Bowers, P. M., 1978b, Research summary; 1977 investigations of the Carlo Creek archaeological site, Central Alaska: report submitted to the University of Alaska Museum, Faurbanks Alaska, 24 p.

Brandau, B. L., and Noakes, J. E., 1978, University of Georgia radiocarbon dates VI: Radiocarbon, v. 20 , no. 3, p. 487-501.

Broecker, W. S., Kulp, J. L., and Tucek, C. S., 1956, Lamont natural radiocarbon measurements III: Science, v. 124 no. 3213, p. 154-165.

Broecker, W. S., and Kulp, J. L., 1957, Lamont natural radiocarbon measurements IV.: Science, v. 126, no. 3287, p. 1324-1344.

Brown, J., 1969, Soil properties developed on the complex tundra relief of northern Alaska: Builetyn Peryglacjalny, no. 18, p. 153-167.

Brown, J., 1965, Radiocarbon dating, Barrow, Alaska: Arctic, v. 18 no. 1, p. 37-48.

Brown, J. and Kreig, R. A., eds., 1983, Guidebook to permafrost and related features along the Elliott and Dalton Highways, Fox to Prudhoe Bay, Alaska: Fourth International Conference on Permafrost, Guidebook 4, 230 p.

Brown, J., Gray, S., and Allan, R. J., 1969, Late Quaternary evolution of a valley-fill, Fairbanks; Part I Geochemistry and stratigraphy of the permafrost: U.S. Army Cold Regions Research Eng. Lab. Tech. Note, 18 p.

Brown, J., Gray, S., and Webster, W., 1967, Chemical and related properties of a permatrost section from Fairbanks, Alaska: U.S. Army Cold Regions Research and Eng. Lab. Tech. Note, 18 p. 
Brown, J., and Sellmann, P. V., 1973, Permafrost and coastal plain history of Arctic Alaska: Arctic Institute of North America Technical Paper No. 25, p. 31-47.

Brown, J., and Sellmann, P. V., 1966, Radiocarbon dating of coastal peat, Barrow, Alaska: Science, v. 153, no. 3733, p. 299-300. (no lab. numbers)

Brubaker, L. B., Garfinkel, H. L., and Edwards, M. E., 1983, A late Wisconsin and Holocene vegetation history from the Central Brooks Range: implications for Alaskan palaeoecology: Quaternary Research, v. 20, no. 2, p. 194-214.

Bryan, A. L., 1978, An overview of Paleo-American prehistory from a circum-Pacific perspective, in, Bryan, A. L., ed., Early Man in America from a Circum-Pacific perspective. University of Alberta Anthropology Department Occasional Papers No. 1, p. 306-327.

Buckley, J., 1973, Isotopes' radiocarbon measurements X: Radiocarbon, v. 15, no. 2, p. 280-298.

Buckley, J. D., Trautman, M. A., and Willis, E. H., 1968, Isotopes' radiocarbon measurements VI: Radiocarbon, v. 10, no. 2, p. 246-294.

Buckley, J., and Valdes-Pages, C., 1981, Teledyne Isotopes' radiocarbon measurements XIl: Radiocarbon, v. 23, no. 3, p. 329-344.

Buckley, J. D., and Willis, E. H., 1970, Isotopes' radiocarbon measurements VIII: Radiocarbon, v. 12, no. 1, p. 87-129.

Buckley, J. D., and Willis, E. H., 1969, Isotopes' radiocarbon measurements VII: Radiocarbon, v. 11, no. 1, p. 53-105.

Byers, D. S., 1962, New England and the arctic: Arctic Institute of North America Technical Paper No. 11, p. 143-153.

Calkin, P. E., and Ellis, J. M., 1981, A cirque-glacier chronology based on emergent lichens and mosses: Journal of Glaciology, v. 27, no. 97, p. 511-515.

Calkin, P. E., and Ellis, J. M., 1980, A lichenometric dating curve and its application to Holocene glacier studies in the Central Brooks Range: Arctic and Alpine Research, v. 12, no. 3, p. 245-264.

Campbell, J. M., 1968, Current Research - Arctic: American Antiquity, v. 33, no. 2, p. 272-278.

Campbell, J. M., 1961, The Tuktu Complex of Anaktuvuk Pass: Anthropological Papers of the Unviversity of Alaska, v. 19, no. 2, p. 61-88.

Carson, C. E., 1968, Radiocarbon dating of lacustrine strands in arctic Alaska: Arctic, v. 21 , no. 1 , p. 12-26.

Carter, L. D., in press, Fossil sand wedges on the Alaskan Arctic Coastal Plain and their paleoenvironmental significance, in, Proceedings Fourth International Conference on Permafrost. 
Carter, L. D., and Galloway, J. P., in press, Lacustrine and eolian deposits of Wisconsinan age at Riverside Bluff in the upper Tanana River Valley, Alaska, in, Coonrad, W. L., and Elliot, R. L., eds., The United States Geological Survey in Alaska: Accomplishments during 1981: U.S. Geological Survey Circular.

Carter, L. D., and Galloway, J. P., 1982, Terraces of the Colville River Delta region, Alaska, in, Coonrad, W. L., ed., 1982, The U. S. Geologcal Survey in Alaska Accomplishments during 1980: U. S. Geologcal Survey Circular 844, p. 49-51.

Carter, L. L., and Galloway, J. P., 1979, Southward-progressing stabilization of Holocene eolian sand on the western Arctic Coastal Plain, in, Johnson, K. M., and Williams, J. R., eds., 1978, The U. S. Geologcal Survey in Alaska - Accomplishments during 1978: U. S. Geologcal Survey Circular 804-B, p. B37-B39.

Carter, L. L., and Robinson, S. W., 1981, Minimum age of beach deposits north of Teshekpuk Lake, Alaskan Arctic Coastal Plain, in, Albert, N. R. D., and Hudson, T., eds., 1981, The U. S. Geologcal Survey in Alaska - Accomplishments during 1979: U.S. Cieologcal Survey Circular 823-B, p. B8-B9.

Carter, L. L., and Robinson, S. W., 1978, Eolian sand and interbedded organic horizons at Keolok Creek on the arctic coastal plain of Alaska; possible regional implications: U. S. Geological Survey Open-file Report 78-320, 26 p.

Chapman, R. M., Yeend, W., Brosge, W. P., and Reiser, H. N., 1982, Reconnaissance geologic map of the Tanana quadrangle, Alaska: U.S. Geological Survey Open-File Report 82-743, 20 p., 1 sheet.

Chatters, R. M., 1968, Washington State University natural radiocarbon measurements I: Radiocarbon, v. 10, no. 2, p. 479-498.

Clark, D. W., 1982, An example of technological change in Prehistory; the origin of a regional ground slate industry in South-Central Coastal Alaska: Arctic Anthropology, v. 19, no. 1 , p. 103-126.

Clark, D. W., 1979, Ocean Bay: an early North Pacific Maritime Culture: National Museum of Man Mercury Series, Archaeological Survey of Canada Paper No. 86, 404 p.

Clark, D. W., 1977, Hananudan Lake; an Ipiutak-related occupation of western interior Alaska: National Museum of Man Mercury Series, Archaeological Survey of Canada Paper No. 71, 168 p.

Clark, D. W., 1974a, The earliest prehistoric culutres of Kodiak Island, Alaska: Arctic Anthropology, v. 11, no. 1, p. 41-46.

Clark, D. W., 1974b, Koniag Prehistory: archaeological investigations at Late prehistoric sites on Kodiak Island, Alaska: Tubinger Monographien zur Urgeschichte Band 1, 271 p.

Clark, D. W., 1974C, Contributions to the Later Prehistory of Kodiak Island, Alaska: National Museum of Man Mercury Series, Archaeological Survey of Canada Paper No. 20,180 p. 
Clark, D. W., 1973, Filaments of prehistory on the Koyukuk River, Northwestern Interior Alaska, in, Raymond, S., and Schledermann, P., eds., International Conference on the Prehistory and Paleoecology of Western Arctic and Sub-Arctic, University of Calgary Archaeological Association, Calgary Canada, p. 33-46.

Clark, D. W., 1972, Archaeology of the Batza Tena obsidian source, West-Central Alaska: Anthropological Papers of the University of Alaska, v. 15, no. 2, p. 1-22.

Clark, D. W., 1970, The Late Kachemak Tradition at Three Saints and Crag Point, Kodiak Island, Alaska: Arctic Anthropology, v. 6, no. 2, p. 73-111.

Clark, D. W., and Clark, M. A., 1975, Fluted points from the Batza Tena obsidian source of the Koyukuk River Region, Alaska: Anthropological Papers of the University of Alaska, v. 17, no. 2, p. 31-38.

Clark, G. H., 1977, Archaeology on the Alaska Peninsula: The Coast of Shelikof Strait 1963-1965: University of Oregon Anthropological Papers No. 13, 247 p.

Colinvaux, P. 1981, Historical Ecology in Beringia; the south land bridge coast at St. Paul Island: Quaternary Reserarch, v. 16, no. 1. p. 18-36.

Cook, J. P., ed., 1977, Pipeline archaeology - Final Report; archaeological investigation along the trans-Alaskan pipeline: Fairbanks, University of Alaska Institute of Arctic Biology, 982 p.

Cook, J. P., 1969, The early Prehistory of Healy Lake, Alaska: Ph.d. dissertation, University of $W$ isconsin.

Coulter, H., Hussey, K., and O'Sullivan, 1960, C-14 Dates relating to the Gubik formation, Northern Alaska: U. S. Geological Survey Professional Paper 400B, p. 350-351.

Crane, H. K., 1956, University of Michigan radiocarbon dates I: Science, v. 124, no. 3224, p. 664-672.

Crane, H. K., and Griffin, J. B., 1968, University of Michigan radiocarbon dates XII: Radiocarbon, v. 10, no. 1, p. 61-114.

Crane, H. K., and Griffin, J. B., 1964, University of Michigan radiocarbon dates IX: Radiocarbon, v. 6, p. 1-24.

Crane, H. K., and Griffin, J. B., 1961, University of Michigan radiocarbon dates VI: Radiocarbon, v. 3, p. 105-125.

Davis, C. W., Link, D. C., Schoenberg, K. M., and Shields, H. M., 1981, Slogging, humping and mucking through the NPR-A; an archaeological interlude $(5$ vols.) Occasional Paper No. 25, Cooperative Park Studies Unit Fairbanks, Alaska.

Denton, G. H., 1974, Quaternary glaciations of the White River Valley, Alaska, with a regional synthesis for the northern St. Elias Mountains, Alaska and Yukon Territory: Geological Society of America Bulletin, v. 85, no. 6, p. 871-892.

Denton, G. H., and Karlen, W., 1977, Holocene glacial and tree-line variations in the White River Valley and Skolai Pass, Alaska and Yukon Territory: Quaternary Research, v. 7, no. 1. p. 63-111. 
Derksen, S. J., 1976, Glacial geology of the Brady glacier region, Alaska: Ohio State University, Institute of Polar Studies Paper No. 60, 97 p.

Detterman, K. L., 1970, Early Holocene warm interval in Northern Alaska: Arctic, v. 23, no. 2, p. 130-131.

Detterman, K. L., Bowsher, A. L., and Dutro, J. T., Jr., 1958, Glaciations on the Arctic Slope of the Brooks Range, Northern Alaska: Arctic, v. 11, no. 1., p. 43-61.

Detterman, R. L., and Reed, B. L., 1973, Surficial deposits of the Iliamna quadrangle, Alaska: U. S. Geologcal Survey Bulletin 1368-A, 64 p.

Detterman, R. L., Reed, B. L., and Meyer, R., 1965, Radiccarbon dates from lliamna Lake, Alaska: U. S. Geologcal Survey Professional Paper 525D, p. D34-D36.

Dixon, E. J., Jr., 1983, Proboscidean fossils from the Alaskan Continental Shelf: Quaternary Research, v. 20, no. 1, p. 113-119.

Dixon, E. J., Jr., 1976, A synthesis of circum-Beringian prehisory and delineation of regions of high archaeological site potential, in, Bering Land Bridge Cultural Resource Study, Final Report, University of Alaska Museum, Fairbanks, Alaska. p. 146-212.

Dixon, E. J., Jr., 1975, The Gallagher Flint Station, an early man site on the North Slope, Arctic Alaska, and its role in relation to the Bering Land Bridge: Arctic Anthropology, v. 13, no. 1, p. 58-75.

Dorn, T. F., Faurhall, A. W., Schell, W. R., and Takashima, Y., 1962 Radiocarbon dating at the University of Washington I: Radiocarbon, v. 4 p. 1-12.

Dumond, D. E., 1981, Archaeology on the Alaska Peninsula: the Naknek Region, 19601975: University of Orgeon Anthropological Papers No. 21, 277 p.

Dumond, D. E., 1980, The Archaeology of Alaska and the peopling of America: Science, v. 209, no. 4460 , p. $984-991$.

Dumond, D. E., 1969, The prehistoric pottery of southwestern Alaska: Anthropological Papers of the University of Alaska, v. 14, no. 2, p. 19-42.

Dumond, D. E., 1968, On the presumed spread of slate grinding in Alaska: Arctic Anthropology, v. 5, no. 1, p. 82-91.

Dumond, D. E., 1965, On Eskaleutian linguistics; archaeology and prehistory: American Anthropologists, v. 67, p. 1231-1257.

Dumond, D. E., 1964, A note on the prehistory of southwestern Alaska: Anthropological Papers of the University of Alaska, v. 12, no. 1, p. 33-45.

Dumond, D. E., 1962, Preliminary report on excavations in Southwest Alaska, in, Dahlgren, G., ed., Science in Alaska 1961 Proceedings Twelfth Alaska Science Conference, Edwards Brothers, Inc., Michigan, p. 3-4. 
Dumond, D. E., Henn, W., and Stuckenrath, R., 1976, Archaeology and prehistory on the Alaska Peninsula: Anthropological Papers of the University of Alaska, v. 18, no. 1, p. 17-29.

Elliot, R. L., Koch, R. D., and Robinson, S. W., 1981, Age of basalt flows in the Blue River Valley, Bradfield Canal quadrangle, in, Albert, N. R. D., and Hudson, T., eds., The U. S. Geological Survey in Alaska - Accomplishments during 1979: U. S. Geological Survey Circular 823-B, p. 115-116.

Ellis, J. M., Hamilton, T. D., and Calkin, P. E., 1981, Holocene glaciation of the Arrigetch Peakes, Brooks Range, Alaska, Arctic, v. 34, no. 2, p. 151-168.

Everett, K. R., 1979, Evolution of the soil landscape in the sand region of the Arctic Coastal Plain as emplified at Atkasook, Alaska, Arctic, v. 32, no. 3, p. 207-223.

Everett, K. R., 1971, Composition and gensis of the organic soils of Amchitka Island, Aleutian Island, Alaska: Arctic and Alpine research, v. 3, no. 1., p. 1-16. (no lab. numbers)

Fairhall, A. W., Young, A. W., and Erickson, J. L., 1976, University of Washington dates IV, Radiocarbon, v. 18, no. 2, p. 221-239.

Farrand, W. K., 1961, Frozen mammoths and modern geology, Science, v. 133, no. 3455, p. 729-735.

Fernald, A. I., 1965a, Late Quaternary chronology, Upper Tanana River Valley, Eastern Alaska: Cieological Society of America Special Paper no. 82, p. 60-61.

Fernald, A. I., 1965b, Glaciation in the Nabesna River Area, Upper Tanana River Valley, Alaska: U. S. Geologcal Survey Professional Paper 525C, p. C120-C123.

Fernald, A. T., 1965c, Recent history of the upper Tanana River Lowland, Alaska, U. S. Geologcal Survey Professional Paper 525C, p. C124-C127.

Fernald, A. T., 1964, Surficial geology of the Central Kobuk River Valley, Northwestern Alaska: U. S. Geologcal Survey Bulletin 1181-K, 31 p.

Fernald, A. T., 1962, Radiocarbon dates relating to a widespread volcanic ash deposit, eastern Alaska: U. S. Geologcal Survey Professional Paper 450B, P. B29-B30.

Ferrians, O. J., Jr, 1963, Glaciolacustrine diamicton deposits in the Copper River Basin, Alaska: U. S. Geological Survey Professional Paper 475-C p. C121-125.

Ferrians, O. J., Jr., and Nichols, D. R., 1965, Copper River Basin, in, Schultz, C. B., and Sinith, H. T. U., eds., International Association for Quaternary Research, VIIth Congress, Guidebook for Field Conference F, central and south central Alaska: Nebraska Academy of Science, Lincoln, Nebraska, p. 93-114.

Ferrians, O. J., Jr., Nichols, D. R., and Williams, J. R., 1983, Copper River Basin, in, Péwé, T. L., and Reger, R. D., eds., Guidebook to Permafrost and Quaternary Geology along the Richardson and Glenn Highways between Fairbanks and Anchorage, Alaska, Fourth International Conference on Permafrost, Guidebook 1, p. $137-175$. 
Fetler, S., and Shinkwin, A. D., 1978, An analysis of archaeological materials from the Cathedral Mountain area, North-Central Alaska: Anthropological Papers of the University of Alaska, v. 19, no. 1, p. 27-43. (no lab. numbers)

Feulner, A. J., and Schupp, R. G., 1964, Temperature and chemical quality of water from a drilled through permafrost near Bethel, Alaska: U. S. Geologcal Survey Professional Paper 501-D, p. D144-D148.

Fishman, B., Forbes, H., and Lawn, B., 1977, University of Pennsylvania radiocarbon dates XIX: Radiocarbon, v. 19, no. 2, p. 188-228.

Ford, J. A., 1959, Eskimo prehistory in the vicinity of Point Barrow, Alaska, Anthropological Papers of the American Museum of Natural History, v. 47 no. 1, p. $1-272$.

Foster, H. L., 1981, A minimum age for Prindle Volcano, Yukon-Tanana Upland, in, Albert, N. R. D., and Hudson, T., eds., The U.S. Geological Survey in Alaska Accomplishments during 1979: U.S. Geological Survey Circular 823-B, p. B37-B38. (no lab. numbers)

Gal, K., 1982, Appendix I: an annotated and indexed roster of archaeological radiocarbon dates from Alaska, north of $68^{\circ}$ latitude: Anthropological Papers of the University of Alaska, v. 20, no. 1-2, p. 159-180.

Gard, L. M., Jr., 1980, The Pleistocene geology of Amchitka Island, Aleutian Islands, Alaska: U. S. Geological Survey Bulletin 1478, 38 p.

Gfeller, C., Oeschger, H., and Schwarz, U., 1961, Bern radiocarbon dates II, Radiocarbon, v. 3, p. 15-25.

Giddings, J. L., 1961, Cultural continuites of Eskimos: American Antiquity, v. 27, no. 2, p. $155-173$.

Giddings, J. L., 1960, The archaeology of Bering Strait: Current Anthropology, v. 1, no. 2, p. 121-130. (no lab. numbers)

Giddings, J. L., Jr., 1957, The tenuous Beaufort Sea archaeology: Fifth Alaskan Science Conference, Science in Alaska, 1954, p. 94-100.

Goldthwait, R. P., 1966a, Glacial history, in, Mirsky, A., ed., Soil development and ecological sucession in a deglaciated area of Muir Inlet, southeast Alaska: Ohio State University, Institute of Polar Studies Paper No. 20, p. 1-18.

Goldthwalt, K. P., 1966b, Evidence from Alaskan glaciers of major climatic changes, in, Proceedings of the International Symposium on World Climate 8000 B.C. - 0 B.C., J. S. Sawyer, ed., Royal Meterological Society of London, p. 40-53.

Guthrie, R. D., 1976, Terrestrial vertebrates and their effect in the distribution of human habitation sites, in, Bering Land Bridge Cultural Resource Study, Final Report, University of Alaska Museum, Fairbanks, Alaska, p. 115-145.

Guthrie, R. D., 1968, Paleoecology of a Late Pleistocene small mammal commuinity from Interior Alaska: Arctic, v. 21, no. 4, p. 223-244. 
Guthrie, R. D., and Matthews, J. V., Jr., 1971 , The Cape Deciet fauna - Early Pleistocene mammalian assemblage frorn the Alaskan Arctic: Quaternay Research, v. 1, no. 4, p. 474-510.

Hall, E. S., Jr., 1981, Cultural resource site potential: a report for the North Slope Borough's coastal zone management plan, 78 p.

Hamilton, T. D., 1982, A late Pleistocene glacial chronology for the southern Brooks Range; stratigraphic record and regional significance: Geological Society of America Bulletin, v. 93, no. 8, p. 700-716.

Hamilton, T. D., 1981, Episodic Holocene alluviation in the Central Brooks Range, chronology, correlations, and climatic implications, in, Albert, N. R. D.. and Hudson, T., eds., The U.S. Geological Survey in Alaska - Accomplishments during 1979: U.S. Geological Survey Circular 823B, p. B21-B24. (no lab. numbers)

Hamilton, 1. D., 1980a, Quaternary stratigraphic sections with radiocarbon dates Chandler Lake quadrangle, Alaska: U. S. Geological survey Open-File Report 80-79, 28 p.

Hamilton, I D., 1980b, Quaternary stratigraphic sections with radiocarbon dates W Iseman quadrangle, Alaska: U. S. Geological Survey Open-File Report 80-791, 53 p.

Hamilton, T. D., 1979a, Quaternary stratigraphic sections with radiocarbon dates Chandalar quadrangle, Alaska: U. S. Geological Survey Open File Report 79-751, 16 p.

Hamilton, T. D., 1979b, Radiocarbon dates and Quaternary stratigraphic sections Philip Smith Mountains quadrangle, Alaska: U. S. Geological Survey Open-File Report 79866,43 p.

Hamilton, T. D., 1978, Geologic Perspectives on early man in Alaska: American Quaternary Associaiton Fifth biennial meeting, Edmonton, Alberta, Canada (abs.) p. 123-125. (no lab. numbers)

Hamilton, T. D., 1969, Glacial geology of the Lower Atlanta Valley, Brooks Range Alaska: Ceological Society of America Special Paper 123, p. 181-223.

Hamilton, T. D., n.d., Quaternary geology of the Ambler and Killik Regions Brooks Range Alaska: Final Report N.S.F. Grant 1536. 55 p.

Hamilton, 1. D., Ager, T. A., and Robinson, S. W., 1983, Late Holocene ice wedges near Fairbanks, Alaska, USA: Arctic and Alpine Research, v. 15, no. 2, p. 157-168.

Hamilton, 1. D., and Brubaker, L. B., 1983, Quaternary stratigraphic sections with radiocarbon dates, Survey Pass quadrangle, Alaska: U.S. Geological Survey OpenFile Report 83-72, 47 p.

Hamilton, I. D., Calkin, P. E., and Ellis, J. M., 1982, Holocene rlimatic change, alluviation and cirque-glacier expansion in the Brooks Range, Alaska: Geological Society of America 95 th Annual Meeting, Abstracts with Program, v. 17, no. 7, p. 505-506. 
Hamilton, T. D., and Hopkins, D. M., 1982, Correlation of northern Alaskan glacial deposits - a provisional stratigraphic framework, in, Coonrad, W. L., ed., The U.S. Geological Survey in Alaska - Accomplishments during 1980: U.S. Geological Survey Circular 844, p. 15-17.

Hamilton, T. D., Stuckenrath, R., and Stuiver, M., 1980, Itkillik glaciation in the central Brooks Range: radiocarbon dates and stratigraphic record: Geological Society of America - Cordilleran Section 76 th Annual Meeting, Abstracts with Program, v. 12, no. 3, p. 109.

Hamilton, I. D., and Porter, S. C., 1975, Itkillik Glacition in the Brooks Range, Alaska: Quaternary Research, v. 5, no. 4, p. $471-497$.

Harington, C. K., 1981, Pleistocene Saiga antelopes in North America and their environmental implications, in Mahaney, W. C., ed., Quaternary Paleoclimates: Norwich, England, Geo Abstracts, 464 p.

Harington, C. R., 1980a, Radiocarbon dates on some Quaternary mammals and artifacts from northern North America: Arctic, v. 33, no. 4, p. 815-833.

Harington, C. R., 1980b, Pleistocene mammals from Lost Chicken Creek, Alaska: Canadian Journal of Earth Sciences, v. 17, no. 2, p. 168-198.

Harington, C. R., 1978, Quaternary vertebrate faunas of Canada and Alaska and their suggested chronological sequence: Syllogeus No. 15, National Museums of Canada, Ottawa, Canada, 105 p.

Harington, C. R., 1969, Pleistocene remains of the lion-like cat (Panthera atrox) frorn the Yukon Territory and northern Alaska: Canadian Journal of Earth Science., v. 6, no. 5, p. 1277-1288.

Haselton, G. M., 1966, Glacial geology of Muir Inlet, southeast Alaska: Ohio State University, Institute of Polar Studies Paper No. 18, 66 p.

Haynes, C. V., Jr., 1982, Were Clovis progenitors in Beringia?, in, Hopkins, D. M., Miatthews, J. V., Jr., Schweger, C. E., and Young, S. P., eds., Paleoecology of Beringia, Academic Press, New York, p. 383-398.

Haynes, ᄂ. V., Jr., 1978, The Clovis Culture: American Quaternary Association Fifth biennial meeting, Edmonton, Alberta, Canada,(abs.) p. 129-132.

Henn, W., 1978, Archaeology on the Alaska Peninisual: the Ugashik drainage 1973-1975: University of Oregon Anthropological Papers No. 14, 183 p.

Henn, W., 1977, Archaeology and prehistory in the Ugashik River Drainage, Alaska Peninsual: University of Oregon Ph.D. thesis, University Microfilm 77-26,466, Ann Arbor, Michigan, 391 p.

Hester, J. J., 1960, Late Pleistocene extinctior, and radiocarbon dating: American Antiquity, v. 26 , no. 1 , p. 58-77.

Heusser, C. J., 1983, Holocene vegetation history of Prince William Sound Region southcentral Alaska: Quaternary Research, v. 19, no. 3, p. 337-355. 
Heusser, C. J., 1973, Postglacial vegetation in Umnak Island, Aleutian Islands, Alaska: Review of Palaeobotany and Palynology, v. 15, p. 277-285.

Heusser, C. J., 1965, A Pleistocene phytogeographical sketch of the Pacific Northwest and Alaska, in, Wright, H. E., Jr., and Frey, D. G., eds. The Quaternary of the United States. Princeton University Press, p. 469-484.

Heusser, C. J., 1963, Postglacial palynology and archaeology in the Naknek River drainage area, Alaska: American Antiquity, v. 29, no. 1, p. 74-81.

Heusser, C. J., 1959, Radiocarbon dates of peats from North Pacific North America: Radiocarbon, v. 1 p. 29-34.

Heusser, C. J., 1958, Late-Pleistocene environments and chronology of Pacific Coastal Alaska: Proceedings Ninth Alaskan Science Conference, p. 74-76. (no lab. numbers)

Heusser, C. J., 1953, Radiocarbon dating of the thermal maximum in southeastern Alaska: Ecology, v. 34, p. 637-640. (no lab. number)

Holmes, C. E., 1982, Norton influence in the Alaska hinterland: Arctic Anthropology, v. 19, no. 2, p. 133-142.

Holmes, C. E., 1973, Preliminary testing of a microblade site at Lake Minchumina, Alaska, in, Raymond, S., and Schledermann, P., eds., International Conference on the Prehistory and Paleoecology of Western Arctic and Sub-Arctic, University of Calgary Archaeological Association, Calgary, Canada, p. 101-112.

Holmes, G. W., and Foster, H. L., 1968, Geology of the Johnson River Area, Alaska: U. S. Geologcal Survey Bulletin 1249, 49 p.

Holmes, G. W., Hopkins, D. M., and Foster, H. L., 1968, Pingos in Central Alaska: U. S. Geologcal Survey Bulletin 1241-H, 40 p.

Hopkins, D. M., 1982, Aspects of the paleogeography of Beringia during the Late Plesstocene, in, Hopkins, D. M., Matthews, J. V., Jr., Schweger, C. E., and Young, S. P., eds., Paleoecology of Beringia, Academic Press, New York, p. 3-28.

Hopkins, D. M., 1963, Geology of the Imuruk Lake area, Seward Peninsula, Alaska: U. S. Geological Survey Bulletin 1141-C, 101 p.

Hopkins, D. M., Hartz, R. W., and Robinson, S. W., 1979, Record of a prehistoric storm surge in the Wainwright Inlet-Kuk River area, in, Johnson, K. M., and Williams, J. R., eds., 1979, The U. S. Geologcal Survey in Alaska - Accomplishments during 1978: U. S. Geologcal Survey Circular 804-B, p. B29-B31.

Hopkins, D. M., and Robinson, S. W. 1981, Radiocarbon dates from the Beaufort and Chukchi Sea Coasts 1980-1981, in, Hopkins, D. M., and Smith, P. A., U.S. National Oceanic and Atmospheric Admin. Environmental Assessment of the Alaska Continental Shelf Anrual Report of Principal Investigations for the year ending March 1981, Appendix C, p. 191-193.

Hopkins, D. M., Robinson, S. W., and Buckley, J., 1980, Radiocarbon dates from the Beaufort and Chukchi Sea Coast (1979-1980), in, Smith, P., Hartz, R., and Hopkins, D., U.S. National Oceanic and Atmospheric Admin. Environmental Assessment of the 
Alaska Continetnal Shelf Annual Report of Principal Investigations for the year ending March 1980, Appendix E, p. 203-220.

Hopkins, D. M., and Robinson, S. W., 1979a, Radiocarbon dates from the Beaufort and Cnukchı Sea Coast, in, Johnson, K. M., and Williams, J. R., eds., The U. S. Geological Survey in Alaska - Accomplishments during 1978: U. S. Geological Survey Circular 804-B, p. 44-46.

Hopkins, D. M., and Robinson, S. W., 1979b, Radiocarbon dates from the Chukchi and Beaufort Sea Coast, in, Srnith, P. and Hopkins, D., U.S. National Oceanic and Atmospheric Admin. Environmental Assessment of the Alaska Continental Shelf Annual Report of Principal Investigations for the year ending March 1979, Appendix 4, p. 156-163.

Hopkins, D. M., Smith, P. A., and Matthews, J. V., Jr., 1981, Dated wood from Alaska and the Yukon; implications for forest refugia in Beringia: Quaternary Research, v. 15, no. 3, p. 217-249.

Hopkins, D. M., Giterman, R. E., and Matthews, J. V., Jr., 1976, Interstadial mammoth remains and associated pollen and insect fossils, Kotzebue Sound area, northwestern Alaska: Geology, v. 4, no. 3, p. 169-172.

Hubbs, C. L., and Bien, G. S., 1967, La Jolla natural radiocarbon measurements V: Radiocarbon, v. 9, p. 261-294.

Hubbs, C. L., Bien, G. S., and Suess, H. E., 1965, La Jolla Natural Radiocarbon Measurements IV: Radiocarbon, v. 7, p. 66-117.

Humphrey, K. L., 1970, The prehistory of the Arctic Slope of Alaska; Pleistocene cultural relationships between Eurasia and North America, unpublished Ph.D. Dissertation, University of New Mexico.

Ives, P. C., Levin, B., Oman, C. L., and Rubin, M., 1967, U. S. Geologcal Survey radiocarbon dates IX: Radiocarbon, v. 9, p. 505-529.

Ives, P. C., Levin, B., Robinson, R. D., and Rubin, M., 1964, U. S. Geologcal Survey radiocarbon dates VII: Radiocarbon, v. 6, p. 37-76.

Irving, W. N., 1976, Current Research - Far North: American Antiquity, v. 41, no. 2, p. 213-219.

Irving, W. N., 1974, Current Research - Far North: Amerien Antiquity, v. 39, no. 4, p. 621-625.

Irving, W. N., 1962, 1961 Field trip in the western Brooks Range, Alaska; preliminary report: Arctic Anthropology, v. 1, no. 1, p. 76-83.

Karlstrom, T. N. V., 1965, Upper Cook Inlet area and Matanuska River Valley' in, Schultz, C. B., and Smith, H. T. U., eds., International Association for Quaternary Research, VIIth Congress, Guidebook for Field Conference F, central and south central Alaska: Nebraska Academy of Science, Lincoln, Nebraska, p. 114-141.

Karistrom, T. N. V., 1964, Quaternary geology of the Kenai lowland and glacial history of the Cook Inlet region, Alaska. U. S. Geologcal Survey Professional Paper 443, 69 p. 
Karlstrom, 1. N. V., 1961, The glacial history of Alaska; its bearing on paleoclimatic theory: Annals of the New York Academy of Sciences, v. 95, art. 1, p. 290-340.

Kigoshi, K., Suzuki, N., and Fukatsu, H., 1973, Gakushuin natural radiocarbon measurements VIII: Radiocarbon, v. 15, no. 1, p. 42-67.

Kjoller, A., and Odom, S., 1971, Evidence for longevity of seeds and microorganisms in permafrost: Arctic, v. 124, no. 3, p. 230-233.

Kowalski, S. J., 1965, Packard Instrument Company radiocarbon dates I: Radiocarbon, $v$. 7, p. 200-204.

Kowalski, S. J., and Schrodt, A. G., 1966, Packard Instrument Company radiocarbon dates II: Radiocarbon, v. 8, p. 386-389.

Kulp, J. K., Feely, H. W., and Tryon, L. E., 1951, Lamont natural radiocarbon measurements I: Science, v. 114, p. 565-568.

Kulp, J. L., Tryon, L. E., Eckelman, W. R., and Snell, W. A., 1952, Lamont natural radiocarbon measurements II: Science, v. 116, no. 3016, p. 409-414.

Kunz, M. L., 1977, Mosquito Lake Site (PSM 049), in, Cook , J. P., ed., Pipeline arcnaeology - Final Report, archaeological investigation along the trans-Alaska pipeline. raırbanks, University of Alaska Institute of Arctic Biology, 982 p.

Krinsley, U. B., 1965, Birch Creek Pingo: U. S. Geologcal Survey Professional Paper 525C, p. C133-C136.

Krueger, H. W. and Weeks, C. F., 1966, Geochron Laboratories, Inc., radiocarbon measurements II: Radiocarbon, v. 8, p. 142-160.

Laguna, F. de., 1962, Intemperate reflections on arctic and subarctic archaeology: Arctic Institute of North America Technical Paper No. 11, p. 164-169.

Laguna, F. de., Riddell, F. A., McGeern, D. F., Lane, K. S., and Freed, J. A., 1964, Archaeology of the Yakutat Bay Area, Alaska: Smithsonian Institution Bureau of American Ethnology Bulletin 192, 245 p.

Larsen, H., 1982, An artifactual comparison of finds of Norton and related cultures: Arctic Anthropology, v. 19, no. 2, p. 53-58.

Larsen, H., 1968, Trail Creek; final report on the excavation of two caves on Seward Peninsula, Alaska: Acta Arctica, no. 15, p. 7-79.

Larsen, H., 1954, The position of Ipiutak in Eskimo culture: American Antquity, v. 20, no. 1, p. 74-79.

Larsen, H., 1953, Archaeological investigations in Alaska since 1939: Polar Record, v. 6, no. 45 , p. $293-607$.

Laughlin, w. J., 1975, Aleuts: ecosystems, Holocene history and Siberian origin: Science, v. 189 , no. 4202 , p. 507-515. 
Laughlin, W. S., 1962, Bering Strait to Puget Sound: dichotomy and affinity between Eskimo-Aleuts and American Indians: Arctic Institute of North America Technical Paper No. 11, p. 113-125.

Laughlin, S. B., Laughlin, W. S., and McDowell, M. E., 1975, Anangula Blade site excavations 1972 and 1973: Anthropological Papers of the University of Alaska, v. 17 , no. 2, p. 39-48.

Lawn, B., 1975, University of Pennsylvania radiocarbon dates XVIII: Radiocarbon, v. 17, no. 2, p. 196-215.

Lawn, B., 1974, University of Pennsylvania radiocarbon dates XVII: Radiocarbon, v. 16, no. 2, p. 219-239.

Lawn, B., 1973, University of Pennsylvania radiocarbon dates XV: Radiocarbon, v. 15, no. 2, p. 367.

Lawn, B., 1971, University of Pennsylvania radiocarbon dates XIV: Radiocarbon, v. 13, no. 2, p. 363-377.

Levin, B., Ives, P. C., Oman, C. L., and Rubin, M., 1965, U. S. Gologcal Survey radiocarbon dates VIII: Radiocarbon, v. 7, p. 372-398.

Libby, W. F., 1955, Radiocarbon dating: 2 d. ed., Chicago, University of Chicago Press, $175 \mathrm{p}$.

Libby, W. F., 1954, Chicago radiocarbon dates IV: Science, v. 119, p. 135-140.

Libby, W. F., 1951, Radiocarbon dates II: Science, v. 114, p. 291-296.

Lippold, L., 1972, Mammalian remains from Aleutian archaeological sites; a preliminary report: Arctic Anthropology., v. 9, no. 2, p. 113-114. (no lab. numbers)

Liu, C. L., and Coleman, D. D., 1981, Illinois State Geoloigical Survey radiocarbon dates VII: Radiocarbon, v. 23, no. 3, p. 352-383.

Livingstone, D. A., 1957, Pollen analysis of a valley fill near Umiat, Alaska: American Journal of Science, v. 255, no. 4, p. 254-260. (no lab. numbers)

Lobdell, J. E., 1981, The Putuligayuk River Delta Overlooks site; fragile traces of ancient man at Prudhoe Bay, Beaufort Sea, Alaska: Environmental Conservation Department, ARCO Alaska, Inc., Anchorage, Alaska.

Long, A., 1965, Smithsonian Institution radiocarbon measurements II: Radiocarbon, v. 7, p. 245-256.

Long, A., and Muller, A. B., 1981, Arizona Radiocarbon dates X: Radiocarbon, v. 23, no. 2, p. 191-217,

Lowdon, J. A., and Blake, W., Jr., 1979, Geological Survey of Canada Radiocarbon Dates XIX: Geological Survey of Canada Paper 79-7, 58 p.

Lowdon, J. A., Wilmeth, R., and Blake, W., Jr., 1969, Geological Survey of Canada radiocarbon dates VIII: Radiocarbon, v. 11, no. 1, p. 22-42. 
Madden, C. T., 1981, Mammotins of North America: unpublished Ph.d. dissertation, University of Colorado, $271 \mathrm{p}$.

Marsters, B., Spiker, E., and Rubin, Ni., 1969, U. S. Geologcal Survey radiocarbon dates X: Radiocarbon, v. II, no. 1, p. 210-227.

Matthews, J. V., Jr., 1982, East Beringia during Late Wisconsin time: a review of the biotic evidence, in, Hopkins, D. M., Matthews, J. V., Jr., Schweger, C. E., and Young, S. P., eds., Paleoecology of Beringia, Academic Press, New York, p. 127-152. (lab. numbers with references, no radiocarbon dates)

Matthews, J. V., Jr., 1974a, Wisconsin environment of interior Alaska; pollen and macrofossil analysis of a 27-meter core from the Isabella Basin ( $F$ aribanks, Alaska): Canadian Journal of Earth Science, v. 11, no. 6, p. 828-84l.

Matthews, J. V., Jr., 1974b, Quaternary environments at Cape Deceit (Seward Peninsula, Alaska); evolution of a tundra ecosystem: Geological Society of America Bulletin, v. 85 , no. 9, p. 1353-184.

Matthews, J. V., Jr., 1970, Quaternary environmental history of interior Alaska; pollen samples from organic colluvium and peats: Arctic and Alpine Research, v. 2, no. 4, p. $24 \mid-251$.

Matthews, J. V., Jr., 1968, A paleoenvironmental analysis of three late Pleistocerie Coleopterons assemblages from Fairbanks, Alaska: Quaesiones entmologica, v. 4, p. $241-251$.

Macartney, A. P., 1974, Prehistoric cultural itergration along the Alaska Peninsula: Anthropological Papers of the University of Alaska, v. 16, no. 1, p. 59-84.

MicCartney, A. P., 1969, Prehistoric Aleut influence at Port Moller: Anthropological Papers of the University of Alaska, v. 14, no. 2, p. 1-17. (no lab. numbers)

McCulloch, D. and Hopkins, D., 1966, Evidence for an early recent warm interval in northern Alaska: Geological Society of America Bulletin, v. 77, no. 10, p. 1089-1108.

MicCulloch, D. S., Taylor, D. W., and Rubin, M., 1965, Stratigraphy, non-marine mollusks, and radiometric dates from Quaternary Deposits in the Kotzebue Sound Area, western Alaska: Journal of Geology, v. 73, no. 3, p. 442-453.

McGhee, R., 1971, Current Research - Far North: American Antiquity, v. 36, no. 4, p. 489-493.

Mckenzie, G. D., 1970, Glacial geology of Adams Inslet, southeastern Alaska: Ohio State University, Institute of Polar Studies Report 25, $121 \mathrm{p}$.

Mckenzie, G. D., and Goldthwait, R. P., 1971, Glacial history of the last eleven thousand years in Adams Inlet, Southeastern Alaska: Geological Society of America, Bulletin, v. 82, no. 7, p. 1767-1782.

Mickelson, D. Mi., 1973, Nature and rate of basal till deposition in a stagnating ice mass Burroughs Glacier, Alaska: Arctic and Alpine Research, v. 5, no. 1, p. 17-28. 
Mickelson, D. M., 1971 , Glacial geology of the Burroughs glacier area, southeastern Alaska: Ohio State University, Institute of Polar Studies Paper No. 60, 97 p.

Mielke, J. E., and Long, A., 1969, Smithsonian Institution radiocarbon measurements V: Radiocarbon, v. 11, no. 1, p. 163-182.

Miller, R. D., 1973a, Two diamictons in a landslide scarp in Admirality Island, Alaska, and the tectonic insignificance of an intervenning peat bed: U. S. Geologcal Survey Journal of Research, v. 1, p. 309-314.

Miller, R. D., 1973b, Gastineau Channel Formation, a composite glaciomarine deposit near Juneau, Alaska: U. S. Geologcal Survey Bulletin, 1394-C, 20 p.

Miller, R. D., and Dobrovolny, E., 1957, Pleistocene history of the Anchorage area, Alaska: Science in Alaska 1957 Proceedingsd Eighth Alaskan Science Conference, p. 133-134.

Mobley, C. M., 1982, The Landmark Gap Trail site, Tangle Lakes, Alaska; another perspective on the Amphitheater Mountain Complex: Arctic Anthropology, v. 19, no. 1, p. 81-102.

Morlan, R. E., 1977, Fluted point makers and the extenction of Arctic-steepe biome: Canadian Journal of Archeology, v. 1, p. 95-108.

Morlan, R. E., and Cinq-Mars, J., 1982, Ancient Beringians: human occupation in the Late Pleistocene of Alaska and the Yukon Territory, in, Hopkins, D. M., Matthews, J. V., Jr., Schweger, C. E., and Young, S. P., eds., Paleoecology of Beringia, Academic Press, New York, p. 353-382.

Naeser, N. D., Westgate, J. A., Hughes, O. L., and Pewe, T. L., 1982, Fission-track ages of late Cenozoic distal tephra beds in the Yukon Territory and Alaska: Canadian Journal of Earth Sciences, v. 19, no. 11, p. 2167-2178.

Nelson, K. E., 1982, Late Quaternary environments of the western arctic slope, Alaska: unpublished Ph.d. dissertation, University of Washington, 146 p.

Nelson, K. E., 1979, Quaternary environments of the arctic slope of Alaska: unpublished master's thesis, University of Washington.

Noakes, J. E., and Brandau, B. L., 1974, University of Georgia radiocarbon dates III: Kadiocarbon, v. 16, no. 1, p. 131-141.

Noakes, J. E., Stipp, J. J., and Hood, D. W., 1964, Texas A \& M University radiocarbon dates 1: Radiocarbon, v. 6, p. 189-193.

Nowak, M., 1982, The Norton Period of Nunivak Island - internal change and external influence: Arctic Anthropology, v. 19, no. 2, p. 75-92.

Nowak, M., 1970, A preliminary report on the archieology of Nunivak Island, Alaska: Anthropological Papers of the University of Alaska, v. 15, no. 1, p. 19-32.

Oeschger, H., Riesen, T., and Lerman, J. C., 1970, Bern radiocarbon dates VII: Radiocarbon, v. 12, no. 2, p. 358-384. 
Ogden, J. G., III, and Hay, R. J., 1973, Ohio Wesleyan University natural radiocarbon measurernents V: Radiocarbon, v. 15, no. 2, p. 350-366.

Okada, H., and Okada, A., 1974, Preliminary report of the 1972 excavations at Port moller, Alaska: Arctic Anthropology, v. 11, supplement, p. 112-124.

Olson, E. A., and Broecker, W. S., 1961, Lamont natural radiocarbon measurements VII: Radiocarbon, v. 3, p. 141-175.

Olson, E. A., and Broecker, W. S., 1959, Larnont natural radiocarbon measurements V: Radiocarbon, v. 1, p. 1-28.

Olson, E. A., and Broecker, W. S., 1958, Sample contamination and reliability of radiocarbon dates: New York Academy of Sciences Transactions, Ser. II, v. 20, no. 7, p. 593-604.

Parrish, L. L., 1980, A record of Holocene changes from St. George Island, Pribilof Islands, Alaska: Institute of Polar Studies Report No. 75, The Ohio State University, $45 \mathrm{p}$.

Pearson, F. J., Jr., Davis, E. M., Tamers, M. A., and Johnstone, R. W., 1965, University of Texas radiocarbon dates III: Radiocarbon, v. 7, p. 296-314.

Péwé, T. L., 1975a, Quaternary geology of Alaska: U. S. Geologcal Survey Professional Paper 835, $145 \mathrm{p}$.

Péwé, T. L., 1975b, Quaternary stratigraphic nomenclature in unglaciated Central Alaska: U. S. Geologcal Survey Professional Paper 862, 32 p.

Péwé, T. L., 1968, Loess deposits of Alaska: Internat. Geol. Cong., 23d. Prague 1968 Proc., v. 8, p. 297-309.

Péwé, T. L., 1965a, Fairbanks area, in, Schultz, C. B., and Smith, H. T. U., eds., International Association for Quaternary Research, VIIth Congress, Guidebook for Field Conterence F, central and south central Alaska: Nebraska Academy of Science, Lincoln, Nebraska, p. 6-36.

Péwé, T. L., 1965b, Resume of the Quaternary geology of the Middle Tanana River Valley, in, Schultz, C. B., and Smith, H. T. U., eds., International Association for Quaternary Research, VIIth Congress, Guidebook for Field Conference F, central and south central Alaska: Nebraska Academy of Science, Lincoln, Nebraska, p. 36-54.

Péwé, T. L., 1965c, Resume of Quaternary Geology of the Delta River Area, Alaska Range, in, Schultz, C. B., and Smith, H. T. U., eds., International Association for Quaternary Research, VIIth Congress, Guidebook for Field Conference F, central and south central Alaska: Nebraska Acaderny of Science, Lincoln, Nebraska, p. 55-93.

Péwé, T. L., and Church, R. E., 1962, Age of the spit at Barrow, Alaska: Geological Society of America Bulletin, v. 73, no. 10, p. 1287-1292. (no lab. numbers)

Péwé, T. L., and Holmes, G. W., 1964 Geology of the Mt Hayes D-4 quadrangle, Alaska: U.S. Geological Survey Miscellaneous Geologic Investigations Map I-394. (no lab. numbers) 
Péwé, T. L., and Reger, R. D., 1983a, Middle Tanana River Valley, in, Péwé, T. L., and Reger, R. L., eds., Guidebook to Permafrost and Quaternary Geology along the Kichardson and Glenn Highways between Fairbanks and Anchorage, Alaska, Fourth International Conference on Permafrost, Guidebook 1, p. 4-45.

Péwé, T. L., and Reger, R. D., 1983b, Delta River Area, Alaska, in, Péwé, T. L., and Reger, K. U., eds., Guidebook to Permafrost and Quaternary Geology along the Kichardson and Glenn Highways between Fairbanks and Anchorage, Alaska, Fourth International Conference on Permafrost, Guidebook 1, p. 47-135.

Péwé, T. L., Hopkins, D. M., and Giddings, J. L., Jr., 1965, Quaternary geology and archaeology of Alaska, in, Wright, H. E., Jr., and Frey, D. G., eds., The Quaternary of the United States, Princeton University Press, p. 355-374.

Plafker, G., Hudson, T., Rubin, M., and Dixon, K. L., 1982, Holocene marine terraces and uplift history in the Yakataga seismic gap near Icy Cape, Alaska, in, Coonrad, W. L., ed., 1982, The U. S. Geologcal Survey in Alaska - Accomplishments during 1980: U. S. Geologcal Survey Circular 844, p. 111-115.

Plafker, G., and Miller, D. J., 1957, Recent history of glaciation in the Malaspina District and adjoining bays, Alaska: Science in Alaska 1957 Proceedings Eighth Alaskan Science Conference, p. 132-133.

Porter, L., 1979, Ecology of a Late Pleistocene (Wisconsin) ungulate community near Jack Wade, East-Central Alaska: Master's thesis, University of Washington, 85 p.

Porter, S. C., 1967, Glaciation of Chagvan Bay area, southwestern Alaska: Arctic, v. 20, no. 4, p. 227-246.

Porter, S. C., 1966, Pleistocene geology of Anaktuvuk Pass, Central Brooks Range, Alaska: Arctic Institute of North America Technical Paper No. 18, 100 p.

Porter, S. C., 1964a, Late Pleistocene glacial chronology of the north-central Brooks Range, Alaska: American Journal of Science, v. 262, no. 4, p. 446-460.

Porter, S. C., 1964b, Antiquity of man at Anatuvuk Pass, Alaska: American Antiquity, v. 29, no. 4, p. 493-495.

Powers, W. R., and Hamilton, T. D., 1978, Dry Creek: A Late Pleistocene human occupation in Central Alaska, in, Bryan, A. L., ed., Early Man in America from a Circum-Pacific perspective: University of Alberta Anthropology Department Occasional Papers No 1, p. 72-77.

Preston, R. E., Person, E., and Deevey, E. S., 1955, Yale natural radiocarbon measurements III: Science, v. 122, no. 3177, p. 954-960.

Rainey, F., and Ralph, E. K., 1959, Radiocarbon dating in the Arctic: American Antiquity, v. 24, no. 4 , pt. 1, p. 365-374.

Ralph, E. K., and Ackerman, R. K., 1961, University of Pennsylvania radiocarbon dates IV: Radiocarbon, v. 3, p. 4-14.

Reaniner, K. E., and Ugolini, F. C., 1982, Paleoenvironmental potential of Brooks Range gelifluction deposits: American Quaternary Association Seventh Biennial Meeting, Seattle, Washington (abs.), p. 154. 
Reeburgh, W. S., and Young, M. S., 1976, University of Alaska radiocarbon dates I: Radiocarbon, v. 18, no. 1, p. 1-15.

Reger, D. K., 1982, Preliminary archaeological investigations at the Clam Gulch site, Cook Inlet, Alaska: Alaska Division of Geological and Geophysical Surveys Open-File $172,14 \mathrm{p}$.

Reger, D. R., 1977, An eskimo site near Kenai, Alaska: Anthropological Papers of the University of Alaska, v. 18, no. 2, p. 37-52.

Reger, R. D., and Updike, R. G., 1983, Upper Cook Inlet Region and the Matanuska Valley, in, Péwé, T. L., and Reger, R. D., eds., Guidebook to Permafrost and Quaternary Geology along the Richardson and Glenn Highways between Fairbanks and Anchorage, Alaska, Fourth International Conference on Permafrost, Guidebook 1, p. 185-263.

Reger, R. D , Péwé, T. L., Hadleigh-West, F., and Skaraland, I., 1964, Geology and archaeology of the Yardang Flint Station: Alaska Unviersity Anthropological Papers, v. 12 , no. 2, p. 92-100.

Repenning, C. A., Hopkins, D. M., and Rubin, M., 1964, Tundra rodent in a late Pleistocene fauna from the Tofty district, Central Alaska: Arctic, v. 17, no. 3, p. 177-197.

Rickert, D. A., and Tedrow, J. C. F., 1966, Pedologic investigations on some aeolian deposits of northern Alaska: Soil Science, v. 104, no. 4, p. 250-252.

Richter, D. H., Lamarre, R. A., and Donaldson, D. E., 1973, Soda Creek Springs - Metamorphic waters in the eastern Alaska Range: U. S. Geologcal Survey Journal of Research, v. 1 no. 5, p. 523-528.

Richter, D. H., and Schmoll, H. R., 1973, Geologic Map of the Nabesna C-5 quadrangle, Alaska: U. S. Geologcal Survey Map GQ 1062.

Robinson, S. W., 1977, U. S. Geologcal Survey, Menlo Park, California, radiocarbon measurements I: Radiocarbon, v. 19, no. 3, p. 460-464.

Robinson, S. W., and Trimble, D. A., 1981, U. S. Geologcal Survey, Menlo Park, California, radiocarbon measurements II: Radiocarbon, v. 23, no. 2, p. 305-321.

Robinson, S. W., and Trimble, D. A., 1983, U. S. Geological Survey, Menlo Park, California, radiocarbon measurements III: Radiocarbon, v. 25, no. 1, p. 143-151.

Rubin, M., and Alexander, C., 1960, U. S. Geologcal Survey radiocarbon dates V: Radiocarbon, v. 2, p. 129-185.

Rubin, M., and Alexander, C., 1958, U. S. Geologcal Survey radiocardon dates IV: Science, v. 127, no. 3313, p. 1476-1487.

Rubin, M., and Berthold, S. M., 1961, U. S. Geologcal Survey radiocarbon dates VII: Radiocarbon, v. 3, p. 86-98. 
Rubin, M., and Seuss, H. E., 1956, U. S. Geologcal Survey radiocarbon dates III: Science, v. 123 , no. 3194 , p. $442-448$.

Rubin, M., and Seuss, H. E., 1955, U. S. Geologcal Survey radiocarbon dates II: Science, v. 121, p. 481-488.

Rusnak, G. A., Bowmar, A. L., and Ostlund, H. G., 1964, Miami natural radiocarbon measurements III: Radiocarbon, v. 6, p. 208-214.

Rutherford, A. A., Wittenberg, J., and Wilmeth, R., 1981, University of Saskatchewan radiocarbon dates IX: Radiocarbon, v. 23, no. 1, p. 94-135.

Rutherford, A. A., Wittenberg, J., and Wilmeth, R., 1979, University of Saskatchewan radiocarbon dates VIII: Radiocarbon, v. 21 , no. 1 , p. 48-94.

Rutherford, A. A., Wittenberg, J., and McCallum, K. J., 1975, University of Saskatcnewan radiocarbon dates VII: Radiocarbon, v. 17, no. 3, p. 328-353.

Rutherford, A. A., Wittenberg, J., and McCallum, K. J., 1973, University of Saskatcnewan radiocarbon dates VI: Radiocarbon, v. 15, no. 1, p. 193-211.

Sainsbury, C. L., 1967, Upper Pleistocene features in the Bering Strait area: U. S. Geologcal Survey Professional Paper 575D, p. D203-213.

Sainsbury, C. L., Kachadoorian, R., Carnpbell, R. H., and Scholl, D. W., 1965, Marine platform of probable Sangamon Age, and associated terrace deposits; Cape Thompson Area, nor thwestern Alaska: Arctic, v. 18, no. 4, p. 231-245.

Sancetta, C., and Robinson, S. W., 1983, Diatom evidence on Wisconsin and Holocene events in the Bering Sea: Quaternary Research, v. 20, no. 2, p. 232-245.

Schledermann, P., and Olson, W., 1969, Archaeological survey of C.O.D. Lake area, Minto Flats: Anthropological Papers of the University of Alaska, v. 14, no. 2, p. 67-76. (no lab. numbers)

Schlesier, K. H., 1971, The archaeology of Sedna Creek: Wichita State University Bulletin, v. 47, no. 4, University Studies, No. 89, Witchita, Kanasas.

Schmoll, H. R., Dobrovolny, E., and Gardner, C. A., 1981, Prelimanary geologic map of Fire Island, Muncipality of Anchorage, Alaska: U.S. Geological Survey Open-File Report 81-552, 5 p.

Schmoll, H. R., Szabo, B. J., Rubin, M., and Dobrovolny, E., 1972, Radiometric dating of marine shells from the Bootlegger Cove clay, Anchorage Area, Alaska: Geological Society of America Bulletin, v. 83, no. 4, p. 1107-1114.

Schweger, C. E., 1982, Late Pleistocene vegetation of eastern Beringia: pollen analysis of dated alluvium, in, Hopkins, D. M., Matthews, J. V., Jr., Schweger, C. E., and Young, S. P., eds., Paleoecology of Beringia, Academic Press, New York, p. 95-112.

Schweger, C. E., 1981, Chronology of Late Glacial events from the Tangle Lake, Alaska Range, Alaska: Arctic Anthropology, v. 18, no. 1, p. 97-101. 
Schweger, C. E., 1976, Late Quaternary paleoecology of the Onion Portage region, northwestern Alaska: Ph.D. dissertation, University of Alberta, Edmonton, Alberta, $183 \mathrm{p}$.

Sellmann, P. V., 1972, Additional information on the geology and properties of materials exposed in the USA-CRREL permafrost tunnel: U.S. Army Cold Regions Research and Eng. Lab. Spec. Rept., 16 p.

Sellmann, P. V., 1967, Geology of the USA-CRREL permafrost tunnel, Fairbanks, Alaska: U.S. Army Cold Regions Research and Eng. Lab. Tech. Rept. 199, 33 p.

Sellmann, P. V., and Brown, J., 1973, Stratigraphy and diagnesis of perennially frozen sediments in the Barrow Region, Alaska, in, Permafrost: The North American contribution to the Second Internation Conference, National Academy of Sciences, Washing ton, D. C., p. 171-181.

Shacklette, H. T., and Rubin, M., 1969, Radiocarbon dating of ash deposits on Amchitka Island, Alaska: U. S. Geologcal Survey Professiona Paper 650B, p. B81-83.

Shaw, R. D., 1982, The expansion and survival of the Norton Tradition on the YukonKuskokwin Delta: Arctic Anthropology, v. 19, no. 2, p. 59-74.

Sheppard, J. C., and Chatters, R. M., 1976, Washington State University natural radiocarbon measurements II: Radiocarbon, v. 18, no. 1, p. 140-149.

Shinkwin, A. D., 1964, Early man in the Brooks Range; the Tuktu-Naiyuk sequence: unpublished Master's thesis, George Washington University.

Spaulding, A. C., 1962, Archaeological investigations on Agattu, Aleutian Islands: Anthropological Papers, Museum of Anthropology, University of Michigan No. 18.

Spiker, E., Kelley, L., and Rubin, M., 1978, U. S. Geologcal Survey radiocarbon dates XIII: Radiocarbon, v. 20, no. 1, p. 139-156.

Spiker, E., Kelley, L., Oman, C., and Rubin, M., 1977, U. S. Geologcal Survey radiocarbon dates XII: Radiocarbon, v. 19, no. 2, p. 332-352.

Stanford, D. J., 1976, The Walakpa site, Alaska; its place in the Birnirk and Thule Cultures: Smithsonian Contributions to Anthropology, no. 20., Sinithsonian Institutition Press, Washington, D.C., 226 p.

Stipp, J. J., Davis, E. M., Noakes, J. E., and Hoover, T. E., 1962, University of Texas radiocarbon dates I: Radiocarbon, v. 4, p. 43-50,

Stuckenrath, R., Jr., Coe, W. R., and Ralph, E. K., 1966, University of Pennsylvania radiocarbon dates IX: Radiocarbon, v. 8, p. 348-385.

Stuckenrath, R., and Mielke, J. E., 1973, Smithsonian Institution radiocarbon measurements VIII: Radiocarbon, v. 15, no. 2, p. 388-424.

Stuckenrath, R., Jr., and Mielke, J. E., 1970, Smithsonian Institution radiocarbon measurements VI: Radiocarbon, v. 12, no. 1, p. 193-204. 
Stuiver, M., 1969, Yale natural radiocarbon measurements IX: Radiocarbon, v. 11, no. 2, p. 545-658.

Stuiver, M., Borns, H. W., and Denton, G. H., 1964, Age of a widespread layer of volcanic ash in the southwestern Yukon Territory: Arctic, v. 17, no. 4, p. 259-260.

Stuiver, M, Deevey, E. S., Jr., and Rouse, I., 1963, Yale Natural radiocarbon measurements VIII: Radiocarbon, v. 5, p. 312-341.

Stuiver, M., Deevey, E. S., 1962, Yale Natural radiocarbon measurements VII: Radiocarbon, v. 4, p. 250-262.

Stuiver, M., and Deevey, E. S., 1961, Yale Vatural radiocarbon measurements Vl: Radiocarbon, v. 3, p. 126-140.

Suess, H. F., 1954, U. S. Geologcal Survey radiocarbon dates I: Science, v. 120, p. 467473.

Sullivan, B. M ., Spiker, E., and Rubin, M., 1970, U. S. Geologcal Survey radiocarbon dates XI: Radiocarbon, v. 12, no. 1, p. 319-334.

Swanston, D. N., 1969, A late-Pleistocene glacial sequence from Prince of Wales Island, Alaska: Arctic v. 22, no. 1, p. 25-33.

Tamers, M. A., 1966, Instituto Venezolano de Investigaciones Cientificas natural radiocarbon measurements II: Radiocarbon, v. 8, p. 204-212.

Tauber, H., 1973, Copenhagen radiocarbon dates X: Radiocarbon, v. 15, no. 1, p. 86-112.

Tauber, H., 1968, Copenhagen radiocarbon dates IX: Radiocarbon, v. 10, no. 2, p. 295327.

Tauber, H., 1964, Copenhagen radiocarbon dates VI: Radiocarbon, v. 6, p. 215-225.

Tauber, H., 1962, Copenhagen radiocarbon dates V: Radiocarbon, v. 4, p. 27-34.

Tauber, H., 1960, Copenhagen natural radiocarbon measurements III Corrections to radiocarbon dates made with solid carbon technique: Radiocarbon, v. 2, p. 5-11.

Tedrow, J. C. F., and Walton, G. F., 1964, Some Quaternary events of northern Alaska: Arctic, v. 17, no. 4, p. 268-271. (no lab. numbers)

Thorson, R. M., and Dixon, E. J., Jr., 1983, Alluvial history of the Porcupine River, Alaska - role of glacial-lake overflow from northern Canada: Geological Society of America Bulletin, v. 94, no. 5, p. 576-589.

Thorson, R. M., Dixon, E. J., Jr., Sinith, G. S., and Batten, A. R., 1981, Insterstadial proboscidean from south-central Alaska; implications for biogeography, geology, and archaeology: Quaternary Research, v. 16 no. 3, p. 40:;-417.

Thorson, R. M., and Hamilton, T. D., 1977, Geology of the Dry Creek Site; a stratified early man site in interior Alaska: Quaternary Research, v. 7, no. 2, p. 149-176. 
Thorson, R. M., Plaskett, D. C., and Dixon, E. J., Jr., 1980, A reported early-man site adjacent to southern Alaska's continental shelf; a geological solution to an archaeological enigma: Quaternary Research, v. 13, no. 2, p. 259-273.

Trainer, F. W., 1961, Eolian Deposits of the Matanuska Valley agricultural area, Alaska: U. S. Geologcal Survey Bulletin 1121-C, 35 p.

Trautman, M. A., 1964, Isotopes' radiocarbon measurements IV: Radiocarbon, v. 6, p. 269279.

Trautrnan, M. A., 1963, Isotopes' radiocarbon measurements III: Radiocarbon, v. 5, p. 6279.

Trautman, M. A., and Walton, A., 1962, Isotopes' Inc. radiocarbon measurements Il: Radiocarbon, v. 4, p. 35-42.

Trautman, M. A., and Willis, E. H., 1966, Isotopes' radiocarbon measurements V: Radiocarbon, v. 8, p. 161-203.

Tucek, C. S., 1977, Radiocarbon, LTD, natural radiocarbon measurements II: Radiocarbon, v. 19, no. 2, p. 245-262.

Turner, C. G., II, Aigner, J. S., and Richards, L. R., 1974, Chaluka stratigraphy, Umnak Island, Alaska: Arctic Anthropology, v. 11, supplement, p. 125-142.

Turner, C. G., II, and Holmes, C. E., 1978, A prehistoric multiple cremation from near Mt. McKinley, Alaska: Anthropological Papers of the University of Alaska, v. 19, no. 1, p. 1-2.

Turner, C. G., II, Mamula, P. W., and Utermohle, C. J., 1982, New anthropological evidence bearing on the issue of new-Aleut origins: Arctic Anthropology., v. 19, no. 1, p. 127-i40.

Turner, C. G., 11, and Turner, J. A., 1974, Progress report on evolutionary anthropological study of Akun Strait District; eastern Aleutians, Alaska: Anthropological Papers of the University of Alaska, v. 16, no. 1, p. 27-57.

Vogel, J. L., and Waterbolk, H. T., 1972, Groningen radiocarbon dates X: Radiocarbon, v. 14 , no. 1 , p. 6-113.

Wahrhaftig, C., 1958, Quaternary geology of the Nenana River Valley and adjacent parts of the Alaska Range, in, Wahrhaftig, C., and Black, R. F., Quaternary and engineering geology in the Central part of the Alaska Range, U. S. Geologcal Survey Professional Paper 293, p. 1-68.

Walker, D. A., Short, S. K., Andrews, J. T., and Webber, P. J., 1981, Late Holocene and present day vegetation Prudhoe Bay and Atigun River, Alaska Arctic Slope: Arctic and Alpine Research, v. 13, no. 2, p. 153-172.

Walton, A., Trautman, M. A., and Friend, J . P., 1961, Isotopes' radiocarbon measurements I: Radiocarbon, v. 3, p. 47-59.

Weber, F. R., Hamilton, T. D., Hopkins, D. M., Repenning, C. A., and Haas, H., 1981, Canyon Creek; a Late Pleistocene vertebrate locality in Interior Alaska: Quaternary Research, v. 16, no. 2, p. 167-180. 
Weber, F. R., and Péwé, T. L., 1970, Surficial and engineering geology of the central part of the Yukon-Koyukuk Lowland, Alaska: U. S. Geologcal Survey Misc. Geologic Investigation Map I-590.

Weber, F. R., and Péwé, T. L., 1961, Engineering geology problems in the Yukon-Koyukuk Lowland, Alaska: U. S. Geologcal Survey Professional Paper 424D, p. D37 1-373.

West, C. E., 1978, Archaeology of the Birches sites, Lake Minchumia, Alaska: unpublished master's thesis, University of Alaska, 179 p.

West, F. H., 1981, The archaeology of Beringia, New York, Columbia University Press, $268 \mathrm{p}$.

West, F. H., 1975, Dating the Denali Complex: Arctic Anthropology, v. 12, no. 1, p. 7681 .

West, F. H., 1973, The significance of typologically early site collections in the Tangle Lakes, Central Alaska: A preliminary consideration, in, Raymond, S., and Schledermann, P., eds., International Conference on the Prehistory and Paleoecology of Western Arctic and Sub-Arctic; University of Calgary Archaeological Association, Calgary, Canada, p. 217-238.

West, F. H., 1967, The Donnelly ridge site and the definition of an early core and blade complex in central Alaska: American Antiquity, v. 32, no. 3, p. 360-382.

Williams, J. K., 1983a, Engineering-geologic maps of northern Alaska, Wainwright quadrangle: U.S. Geological Survey Open-File Report 83-457, 28 p. 2 sheets.

Willarns, J. K., 1983b, Engineering - geologic maps of northern Alaska, Meade River quadrangle: U.S. Geological Survey Open-File Report 83-294, 32 p., 1 sheet.

Williams, J. R., and Coulter, H. W., 1981, Deglaciation and sea-level fluctuations Port Valdez, Alaska, in, Albert, N. R. D., and Hudson, T., eds., 1981, The U. S. Geologcal Survey in Alaska - Accomplishments during 1979: U. S. Geologcal Survey Circular 823-B, p. 76-78.

Williams, J. R., and Ferrians, O. J., Jr., 1961, Late Wisconsin and recent history of the Matanuska Glacier, Alaska: Arctic, v. 14, no. 2, p. 83-90.

Williams, J. R., and Ferrians, O. J., Jr., 1958, Late Wisconsin and recent history of the Matanuska Glacier, Alaska: Science in Alaska 1958 Proceedings Ninth Alaskan Science Conference, p. 90.

Williams, J. R., and Yeend, W. E., 1979, Deep thaw lake basins of the inner Arctic Coastal Plain, Alaska, in, Johnson, K. M., and Williams, J. R., eds., The U. S. Geologcal Survey in Alaska - Accomplishments during 1978: U. S. Geologcal Survey Circular 804-B, p. B29-B31.

Wilson, F. H., and Young, M. S., 1976, Radiocarbon dates for Alaska, Yukon Territory and British Columbia: Institute of Marine Science, University of Alaska, IMS Report R76-6, 64 p. 
Wilson, I. K., 1978, Archaeological investigations at the Atigun site central Brooks Range, Alaska: National Museum of Canada Mercury Series Archaeological Survey of Canada Paper No. 78.

Workman, W. B., 1983, Current Research - Far North: American Antiquity, v. 48, no. 2, p. 404-410.

Workman, W. B., 1981, Current Research - Far North: American Antiquity, v. 46, no. 2, p. 429-437.

Workman, W. B., 1980, Current Research - Far North: American Antiquity, v. 45, no. 1, p. 184-199.

Workman, W. B., 1977, New data on the radiocarbon chronology of the Kachemak Bay Sequence: Anthropological Papers of the University of Alaska, v. 18, no. 2, p. 31-36.

Workman, W. B., 1973, The cultural significance of a volcanic ash which fell 1400 years ago, in, Raymond, S., and Schledermann, P., eds., International Conference on the Prehistory and Paleoecology of Western Arctic and Sub-Arctic; University of Calgary Archaeological Association, Calgary, Canada, p. 239-261. (no lab. numbers)

Workman, W. B., 1966, Prehistory at Port Moller, Alaska Peninsula, in light of fieldwork in 1960: Arctic Anthropology, v. 3, no. 2, p. 132-153.

Workman, W. B., Lobdell, J. E., and Workman, K. W., 1980, Recent archaeological work in Kacnemak Bay, Gulf of Alaska: Arctic, v. 33, no. 3, p. 385-399.

Yeend, W., 1983, Engineering - geologic maps of northern Alaska, Lookout Ridge quadrangle: U.S. Geological Survey Open-File Report 83-279, 2 sheets. 


\section{APPENDIX I}

Laboratories which have reported radiocarbon determinations for Alaskan material

Radiocarbon laboratories - United States

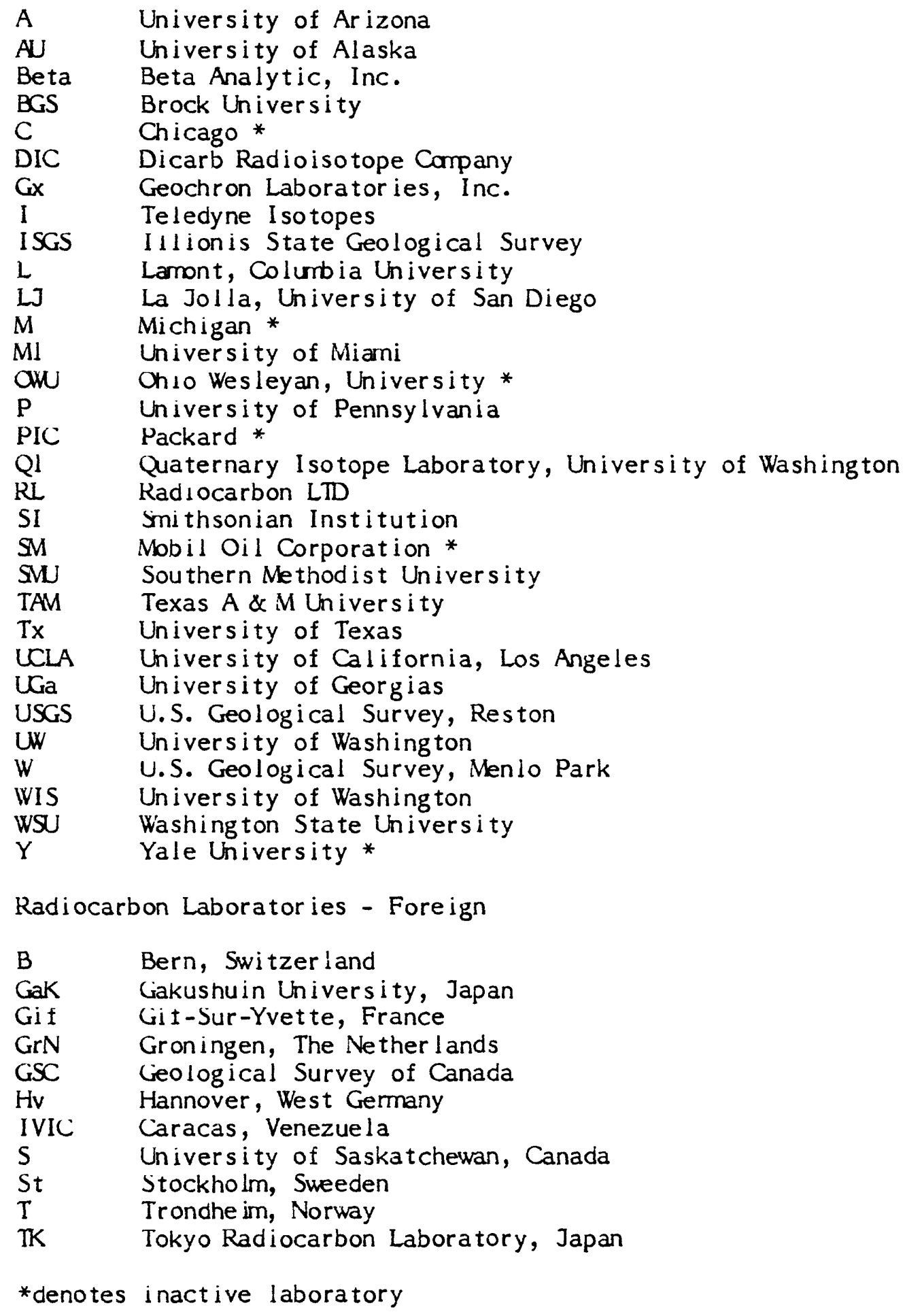


APPENDIX II

\section{CITATIONS - SCIENCE}

Author

Arnold and Libby, 1951

Libby, 1954

Libby, 1951

Broecker and Kulp, 1957

Broecker, et. al., 1956

Kulp, et. al., 1951

Kulp, et. a!., 1952

Crane, 1956

Rubin and Alexander, 1958

Rub in and Suess, 1956

Rubin and Suess, 1955

Suess, 1954

Barendsen, et. al., 1957

Preston, et. al., 1955
Lab.

C

C

C

L

L

L

L

M

W

W

W

W

$\mathrm{Y}$
$\mathrm{Y}$ 
APPENDIDX I I I

\section{CITATIONS - RADIOCARBON}

Author

Long and Muller

Reeburgh and Young, 1976

Gfeller, et. al., 1961

Deschger, et. al., 1970

Kigoshi, et. al., 1973

Vogel and Waterbolk, 1972

Lowdon, et. al., 1969

Krueger and Weeks, 1966

Buckley, 1973

Buckley and Valdes-Pages, 1981

Buckley and Willis, 1970

Buckley and Will is, 1969

Buckley, et. al., 1968

Heusser, 1959

Trautman, 1964

Trautman, 1963

Trautman and Walton, 1962

Trautman and Willis, 1966

Walton, et. al., 1961

Liu and Coleman, 1981

Tamers , 1966

Tauber, 1973

Tauber, 1968

Tauber, 1964

Tauber, 1962

Tauber, 1960

Olson and Broecker, 1961

Olson and Broecker, 1959

Hubbs and Bien, 1967

Hubbs, et. al., 1965

Crane and Griffin, 1972

Crane and Griffin, 1968

Crane and $\mathrm{Gr}$ iffin, 1964

Crane and Griffin, 1961

Lab.

\begin{tabular}{|c|c|c|}
\hline A & $\begin{array}{l}\text { Rusnake, et. al., } 1964 \\
\text { Ogden and Hay, } 1973\end{array}$ & Ml \\
\hline $\mathrm{AU}$ & Fishman, et. al., 1977 & $\mathrm{P}$ \\
\hline B & Lawn, 1975 & $P$ \\
\hline B & Lawn, 1974 & $\begin{array}{l}P \\
P\end{array}$ \\
\hline & Lawn, 1973 & $\mathrm{P}$ \\
\hline GaK & Lawn, 1971 & $\begin{array}{c}0 \\
P\end{array}$ \\
\hline $\mathrm{GrN}$ & $\begin{array}{l}\text { Ralph and Ackerman, } 1961 \\
\text { Stuckenrath, et. al., } 1966\end{array}$ & $\begin{array}{l}\mathrm{P} \\
\mathrm{P}\end{array}$ \\
\hline GSC & Kowalski , 1965 & PIC \\
\hline $\mathrm{Gx}$ & Kowalski and Schrodt, 1966 & PIC \\
\hline I & Tucek, 1977 & $\mathrm{Rl}$ \\
\hline I & Rutherford, et. al., 1981 & $\mathrm{~S}$ \\
\hline I & Rutherford, et. al., 1979 & S \\
\hline I & Ruther ford, et. al., 1975 & S \\
\hline $\begin{array}{l}\text { I } \\
\text { I }\end{array}$ & Rutherford, et. al., 1973 & S \\
\hline I & Long, 1965 & SI \\
\hline I & Mielke and Long, 1969 & SI \\
\hline I & Stuckenrath and Mielke, 1973 & SI \\
\hline$I$ & Stuckenrath and Mielke, 1970 & SI \\
\hline & Noakes, et. al., 1964 & TAM \\
\hline VIC & $\begin{array}{l}\text { Pearseon, et. al., } 1965 \\
\text { Stipp, et. al., } 1962\end{array}$ & $\begin{array}{l}\mathrm{Tx} \\
\mathrm{Tx}\end{array}$ \\
\hline $\mathrm{K}$ & Brandau and Noakes, 1978 & UGa \\
\hline $\begin{array}{l}\mathrm{K} \\
\mathrm{K}\end{array}$ & Noakes and Brandau, 1974 & UGa \\
\hline K & Robinson, 1977 & USGS \\
\hline $\mathrm{K}$ & $\begin{array}{l}\text { Robinson and Trimble, } 1981 \\
\text { Robinson and Trimble, } 1983\end{array}$ & $\begin{array}{l}\text { USGS } \\
\text { USGS }\end{array}$ \\
\hline$L$ & & \\
\hline $\mathrm{L}$ & $\begin{array}{l}\text { Dorn, et. al., } 1962 \\
\text { Fairhall, et. al., } 1976\end{array}$ & $\begin{array}{l}\text { UW } \\
\text { UW }\end{array}$ \\
\hline LeJ & & \\
\hline LJ & $\begin{array}{l}\text { Ives, et. al., } 1967 \\
\text { Ives, et. al., } 1964\end{array}$ & $\begin{array}{l}W \\
W\end{array}$ \\
\hline $\mathrm{MI}$ & Levin, et. al., 1965 & I \\
\hline M & Varsters, et. al., 1969 & W \\
\hline $\mathrm{M}$ & Rubin and Alexander, 1960 & W \\
\hline M & Rubin and Berthold, 1961 & W \\
\hline
\end{tabular}


Spiker, et. al., 1978

Spiker, et. al., 1977

Sullivan, et. al., 1970

Bender, et. al., 1982

WIS

Chat ters, 1968

WSU

Sheppard and Chatters, 1976

WSU

Stuvier, 1969

Stuiver, et. al., 1963

Stuiver and Deevey, 1962

Stuiver and Deevey, 1961

$\mathrm{Y}$

$\mathrm{Y}$

$Y$

$\mathrm{Y}$ 


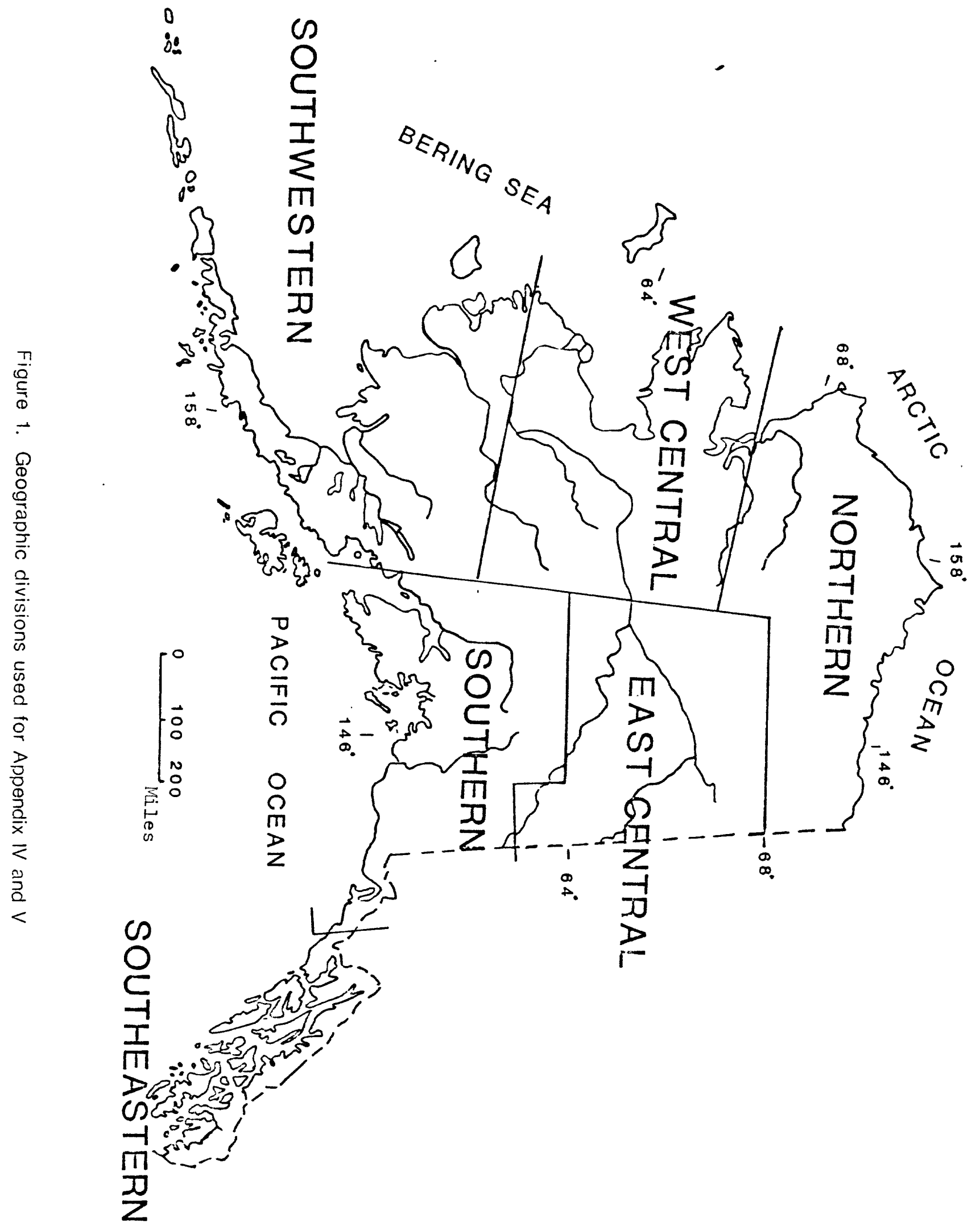


Statewide

Alexander, 1974

Ander son, 1978

Bonnichsen, 1979

Borden, 1979

Borden, 1962

Bryan, 1978

Byers, 1962

Campbel l, 1968

Cook, 1977

Dumond, 1980

Dumond, 1968

Dumond, 1965

Giddings , 1961

Giddings, 1960

Giddings, 1957

Hami 1 ton, 1978

Haynes, 1982

Haynes, 1978

Hester, 1960

Holmes, 1982

Irving, 1976

Irving, 1974

Laguna, 1962

Larsen, 1982

Larsen, 1954

Larsen, 1953

Mechee, 1971

Morlan, 1977

Morlan and Cinq-Mars, 1982

Péwé, et. al., 1965

Rainey and Ralph, 1959

West, 1981

Wilson and Young, 1976

Workman, 1983

Workman, 1981

Workman, 1980

Workman, 1973

Nor thern

Alexander , 1969

Anderson, 1970a

Anderson, 1970b

Campbe 1 l, 1961

Crane and Griffin, 1964

Davis, et. al., 1981

Dixon, 1975

Ford, 1959

Gal, 1982

Hall , 1981
Hami 1 ton, $1979 \mathrm{~b}$

Humphrey, 1970

Irving, 1962

Kunz , 1977

Lawn, 1975

Lobedel1, 1981

Long, 1965

Lowden, et. al., 1969

Porter, 1964a

Porter, 1964b

Ralph and Ackerman, 1961

Sheppard and Chatters, 1976

Shinkwin, 1964

Stanford, 1976

Stuiver and Deevey, 1961

Tauber, 1973

Tauber, 1968

Wilson, 1978

West-Central

Ackerman, 1962

Buckley and Willis, 1969

Clark, 1977

Clark, 1973

Clark, 1972

Clark and McFadyen Clark, 1975

Dixon, 1976

Fi shman, et. al., 1977

Gfeller, et. al., 1961

Holmes , 1973

Larsen, 1968

Lawn, 1975

Lawn, 1973

Lawn, 1971

Libby, 1955

Libby, 1954

Libby, 1951

Ralph and Ackerman, 1961

Rubin and Suess, 1956

Rutherford, et. al., 1981

Rutherford, et. al., 1979

Ruther ford, et. al., 1975

Ruther ford, et . al., 1973

Shaw, 1982

Stuckenrath, et.al., 1966

Tauber, 1973

Tauber, 1968

Tauber, 1964

Tauber, 1962 
Tauber, 1960

West, 1978

East-Central

Cook, 1969

Kigoshi, et. al., 1973

Lawn, 1974

Schledermann and Olsen, 1969

Southwestern

Ackerman, 1973

Ackerman, 1964

Aigner, 1978a

Aigner, 1978b

Aigner, 1978c

Aigner, et. al ., 1976

Arch. Res. Inc., 1970

Black, 1976a,

Black, 1975

Black, 1974

Black and Laughl in, 1964

Buckley, 1973

Buckley and Will is, 1970

Buckley and Willis, 1969

Buckley, et. al., 1968

Byers, 1962

Chatters, 1968

Clark, D., 79

Clark, D., 1977

Clark, D., 1974a

Clark, D., 1974b

Clark, D., 1970

Clark, G., 1977

Crane, 1956

Dumond, 1981

Dumond, 1969

Dumond, 1964

Dumond, 1962

Dumond, et. al., 1976

Fairhall, et. al., 1976

Henn, 1978

Henn, 1977

Ives, et. al., 1964

Laughl in, 1975

Laughl in, 1962

Laughlin, et. al., 1975

Lawn, 1974

Libby, 1955

Libby, 1951a

Lipold, 1972

VeCartney, 1974

McCartney, 1969

Nowak, 1982

Nowak, 1970
Okada and Okada, 1974

Ralph and Ackerman, 1961

Schleiser, 1971

Spaulding, 1962

Stuiver and Deevey, 1962

Trautman, 1964

Turner and Turner, 1974

Turner, et. al., 1982

Turner, et. al., 1974

Workman, 1977

Workman, 1966

Workman, et . al., 1980

Southern

Bowers, 1980

Bowers, 1978a

Bowers , 1978b

Brandau and Noakes, 1978

Fetler and Shinkwin, 1978

Mbbley, 1982

Noakes and Brandau, 1974

Oeschger, et. al., 1970

Powers and Hamilton, 1978

Reger, 1982

Reger, 1977

Reger, et. al., 1964

Rutherford, et. al., 1981

Schweger, 1981

Stuckenrath, et. al., 1966

Thorson and Hami lton, 1977

Turner and Holmes, 1978

West, 1975

West, 1973

West, 1967

Southeastern

Ackerman, et. al., 1979

Buckley, 1973

Chat ters, 1968

Clark, 1982

Laguna, 1962

Laguna, et. al., 1964 
APPENDIX V

GEOLOGY

Statewide

Ager, 1982

Arnold and Libby, 1951

Broecker, et. al., 1956

Guthrie, 1976

Har ing ton, 1980 a

Har ington, 1978

Hester, 1960

Heusser, 1965

Heusser, 1953

Hopkins, 1982

Hopkins, et. al., 1981

Madden, 1981

Mat thews, 1982

Karlstrom, 1961

Péwé, $1975 a$

Péwé, 1968

Péwé, et. al., 1965

Reeburgh and Young, 1976

Robinson and Trimble, 1983

Wilson and Young, 1976

Nor thern

Bender, et. al., 1982

Brown, 1969

Brown, 1965

Brown and Kreig, 1983

Brown and Sellmann, 1973

Brown and Sellmann, 1966

Brubaker, et. al., 1983

Buckley and Valdes-Pages, 1981

Buckley, et. al., 1968

Calkin and Ellis, 1981

Calkin and Ellis, 1980

Carson, 1968

Carter, in press

Carter and Galloway, 1982

Carter and Galloway, 1979

Carter and Robinson, 1981

Carter and Robinson, 1978

Coulter, et. al., 1960

Det terman, 1970

Detterman, et. al. 1958

Ell is, et. al., 1981

Everett, 1979

Fernald, 1964

Hamil ton, 1982

Hamil ton, 1981

Hami l ton, 1980 a

Hamil ton, $1980 \mathrm{~b}$
Hamil ton, 1979 a

Hami 1 ton, $1979 b$

Hami 1 ton, 1969

Hami l ton, n.d.

Hami lton and Brubaker, 1983

Hami 1 ton and Hopkins, 1982

Hamitlon and Porter, 1975

Hamilton, et. al., 1982

Hamilton, et. al., 1980

Har ing ton, 1981

Hopkins and Robinson, 1981

Hopkins and Robinson, 1979a

Hopkins and Robinson, 1979b

Hopkins, et. al., 1980

Hopkins, et. al., 1979

Ives, et. al., 1964

Lawn, 1975

Levin, et. al ., 1965

Livingston, 1957

Mersters, et. al., 1969

Nelson, 1982

Nelson, 1979

Ol son and Broecker, 1961

Ol son and Broecker, 1959

Olson and Broecker, 1958

Pearson, et. al., 1965

Péwé and Church, 1962

Porter, 1966

Porter, 1964a

Reaniner and Ugolini, 1982

Rickert and Tedrow, 1966

Robinson, 1977

Robinson and Trimble, 1981

Rubin and Alexander, 1960

Rub in and Alexander, 1958

Rusnake, et. al., 1964

Sainsbury, et. al., 1965

Schweger, 1982

Schweger, 1976

Sel lmann and Brown, 1973

Spiker, et. al., 1978

Stuckenrath and Mielke, 1972

Stuiver and Deevey, 1961

Stuiver, et. al., 1963

Tedrow and Walton, 1964

Trautman, 1963

Trautman and Walton, 1962

Trautman and Will is, 1960

Walker, et. al., 1981 
Wi 11 i ams, 1983a

Wi 11 i ams, 1983b

Wi 11 iams and Yeend, 1979

Yeend, 1983

West-Central

Guthrie and Mat thews, 1971

Hopk ins, 1963

Hopkins, et. al., 1976

Kulp, et. al., 1952

Levin, et. al., 1965

Marsters, et. al., 1965

Mat thews, 1974b

McCulloch and Hopkins, 1966

Miculloch, et. al., 1965

Rubin and Alexander, 1958

Sainsbury, 1967

Sancetta and Robinson, 1983

Spiker, et. al., 1978

Stuiver, 1969

Stuiver, et. al., 1963

Weber and Péwé, 1970

Weber and Péwé, 1961

East-Central

Ager, 1975

Ager, 1972

Blackwell, 1965

Brown and Kreig, 1983

Brown, et. al., 1969

Brown, et. al., 1967

Buckley, et. al., 1968

Chapman, et. al., 1982

Crane, 1956

Farrand, 1961

Fernald, 1965a

Fernald, 1965b

Fernald, 1965c

Fernald, 1962

Foster, 1981

Guthrie, 1968

Hamilton, et. al., 1983

Har ing ton, $1980 \mathrm{~b}$

Har ington, 1969

Holmes and Foster, 1968

Holmes, et. al., 1968

Ives, et. al., 1964

Kjoller and Odom, 1971

Kowalski , 1965

Kowalski and Schrodt, 1966

$\mathrm{Kr}$ insley, 1965

Krueger and Weeks, 1966

Kulp, et. al., 1952

Libby, 1955
Libby, 1951

Long and Miller, 1981

Lowdon and Blake, 1979

Vlarsters, et. al., 1969

Mat thews, 1974

Mat thews, 1970

Va t hews, 1968

Mi elke and Long, 1969

Naeser, et. al., 1982

Noakes, et. al., 1964

Ol son and Broecker, 1961

Péwé, $1975 \mathrm{~b}$

Péwé, 1965a

Péwé, 1965b

Péwé, $1965 \mathrm{c}$

Péwé and Reger, 1983a

Péwé and Reger, 1983b

Porter, 1979

Repenning, et. al., 1964

Robinson and $\mathrm{Tr}$ imble, 1981

Rubin and Alexander, 1960

Rubin and Alexander, 1959

Rubin and Berthold, 1961

Sellman, 1972

Sel lman, 1967

St ipp, et. al., 1962

Stuckenrath and Mielke, 1973

Stuckenrath and Mielke, 1970

Stuiver, et. al., 1964

Suess, 1954

Tamers, 1966

Thorson and Dixon, 1983

Trautman and Willis, 1966

Tucek, 1977

Weber, et. al., 1981

Southwestern

Barr, et.al., 1973

Black, 1976

Black, 1976

Black, 1975

Black, 1974

Buckley and Willis, 1970

Col invaux, 1981

Crane and Griffin, 1961

Detterman and Reed, 1973

Det terman, et. al.; 1965

Everet t, 1971

Feulner and Schupp, 1964

Gard, 1980

Heusser, 1973

Heusser, 1963

Ives, et. al., 1967

Kulp, et. al., 1952 
Levin, et. al., 1965

Marsters, et. al., 1970

Parrish, 1980

Porter, 1967

Shacklette and Rubin, 1969

Spiker, et. al., 1978

Stuckenrath and Mielke, 1973

Stuiver, 1969

Trautman and Willis, 1966

Southern

Ager, 1976

Ager and Sims, 1981

Ager and Sims, 1981

Bartsch-Winkler, et. al., 1983

Bowers, 1978a

Carter and Galloway, in press

Denton, 1974

Denton and Karlen, 1977

Dixon, 1983

Fairhall, et. al., 1976

Ferrians, 1963

Ferrians and Nichols, 1965

Ferrians, et. al., 1983

Heusser, 1983

Heusser, 1959

Heusser, 1958

Hubbs and Bien, 1967

Hubbs, et. al., 1965

Ives, et. al., 1967

Ives, et. al., 1964

Kalstram, 1965

Karlstrom, 1964

Krueger and Weeks, 1966

Kulp, et. al., 1952

Kulp, et. al., 1951

Levin, et. al., 1965

Liu and Coleman, 1981

Long, 1965

Marsters, et. al., 1970

Marsters, et. al., 1969

Miller and Dobrovolny, 1957

Deschger, et. al., 1970

$\mathrm{Ol}$ son and Broecker, 1959

Olson and Broecker, 1958

Péwé and Holmes, 1964

Plafker and Miller, 1957

Plafker, et. al., 1982

Reger and Updike, 1983

Richter and Schmol1, 1973

Richter, et. al., 1973

Robinson and Trimble, 1981

Rubin and Alexander, 1960

Rubin and Alexander, 1958
Rub in and Suess, 1954

Schmoll, et. al., 1981

Sctmo l l, et. al., 1972

Spiker, et. al., 1977

Stuiver, 1969

Suess, 1954

Thorson and Hamilton, 1977

Thorson, et. al., 1981

Thorson, et. al., 1980

Trainer, 1961

Trautman, 1963

Trautman and Willis, 1966

Vogel and Waterbolk, 1972

Wahrahf tig, 1958

Williams and Coulter, 1981

Wi 11 iams and Ferrians, 1961

Williams and Ferrians, 1958

Southeastern

Barendsen, et. al., 1957

Broecker and Kulp, 1957

Buckley and Will is, 1969

Crane and Gr iffin, 1968

Derksen, 1976

Dorn, et. al., 1962

Elliot, et. al., 1981

Goldthwait, 1966a

Goldthwait, 1966b

Haselton, 1966

Heusser, 1959

Heusser, 1958

Heusser, 1953

Ives, et. al., 1967

Marsters, et. al., 1970

Marsters, et. al., 1969

McKenzie, 1970

McKenzie and Goldthwait, 1971

Mickelson, 1973

Mickelson, 1971

Miller, 1973a

Miller, 1973b

Ogden and Hay, 1973

Olson and Broecker, 1959

Preston, et. al., 1955

Rubin and Alexander, 1960

Spiker, et. al., 1978

Spiker, et. al., 1977

Stuckenrath and Mielke, 1973

Swanston, 1969

Walton, et. al., 1961 